\title{
The anatomy of the Milošević trial (2001-2006)
}

\author{
Hirad Abtahi ${ }^{1}$ and Grant Dawson ${ }^{2^{*}}$
}

\section{Introduction}

Slobodan Milošević has the infamous honour of being the first post-World War II former head of state to be brought before and tried by an international criminal tribunal. ${ }^{1}$ As noted by Human Rights Watch, "the trial of Milosevic marked an end of the era when being a head of state meant immunity from prosecution. Since then other former heads of state, including Saddam Hussein and Charles Taylor, have been brought to justice" (Human Rights Watch 2006, p. 1).

It is difficult to envision a more complex trial than the trial of Slobodan Milošević. Not only were there many legal issues in respect of the proceedings-such as Miloševićs former head of state status, his decision to represent himself, and his poor health—but also three separate trials were to be conducted together into one proceeding, encompassing four armed conflicts, those that unfolded in Slovenia, Croatia, Bosnia and Herzegovina, and finally Kosovo. The last of these involved the participation of the North Atlantic Treaty Organization (NATO) in its first armed conflict.

This article guides the reader through the major phases of the trial. "Guide" is an important word in this context, and one that is chosen carefully. The immensity and complexity of the case renders it somewhat impenetrable to a person who is approaching it for the first time and who possesses a sincere interest in actually delving into the labyrinth of proceedings. It is akin to a mountaineer standing at the base of a mountain, looking up, and not being able to see the top. A guide would be advisable. This guide to the Milošević trial is therefore intended to guide the reader from the start of the proceedings to the very end, while highlighting and explaining the more significant events. Each of these events can then be examined in more detail, through reference to the primary documentation, which is available on the

\footnotetext{
* Correspondence: dawsongrant@hotmail.com

${ }^{2}$ Organisation for the Prohibition of Chemical Weapons, Johan de Wittlaan

32, 2517 JR The Hague, The Netherlands

Full list of author information is available at the end of the article
}

website of the International Criminal Tribunal for the former Yugoslavia (ICTY), as well as commercial legal research tools, such as Lexis-Nexus and Westlaw.

Due to the ultimate lack of resolution of the trial following the death of Milošević, it is possible that a case of this size and complexity will never be seen again. But the unique and novel circumstances that made up the proceedings served in many ways as an experimental cauldron of procedural and substantive legal innovations, which should be-and indeed already have been-exploited for future trials of this kind. With the passing of time and the initiation of proceedings against other former or serving heads of state, new generations of lawyers and academics may not immediately realise how unlikely the Milošević proceedings seemed in the 1990s and how fundamentally they impacted on international criminal justice. To address this, the article provides a condensed description of the main phases of the proceedings. It will first set out the context in which the Milošević proceedings began, in order to provide a detailed analysis of the pre-trial phase and trial phase, before describing the final stages of the proceedings.

\section{Prologue: from the former Yugoslavia to The Hague}

While the rise and fall of Slobodan Milošević and the surrounding geopolitical events have been described elsewhere many times (see, e.g. Silber and Little 1996; Judah 2002; Stephen 2004), a briefly sketched overview of the principal events that led to the proceedings against Milošević may assist those readers not immediately familiar with them.

Slobodan Milošević, who was of ethnic Montenegrin origin, was born in Serbia on 20 August 1941. He grew up in the Socialist Federative Republic of Yugoslavia (SFRY) under Tito during the Cold War. A lawyer by training, he was appointed in 1984 as head of the Belgrade Communist Party and, 2 years later, head of the Serbian Communist Party (Silber and Little 1996,
焦 Springer

(c) 2016 Abtahi and Dawson. Open Access This article is distributed under the terms of the Creative Commons Attribution 4.0 International License (http://creativecommons.org/licenses/by/4.0/), which permits unrestricted use, distribution, and reproduction in any medium, provided you give appropriate credit to the original author(s) and the source, provide a link to the Creative Commons license, and indicate if changes were made. 
pp. 42-43; Judah 2002, pp. 50-54; Stephen 2004, pp. 33-37; ICTY Case Information Sheet).

On 24 April 1987, Milošević travelled to Kosovo Polje where he gave his famous speech to a group of Kosovo Serbs, who were complaining of mistreatment by the Kosovo Albanians. Milošević entered the agitated crowds of Kosovo Serbs and made his famous statement, "No one should dare to beat you!" This incident symbolised what would become the return of a certain type of Serbian nationalism throughout the 1990s. In 1989, Kosovo's autonomy was revoked, and Milošević was appointed President of the Presidency of the Socialist Republic of Serbia. On 28 June 1989, Milošević addressed a crowd of approximately one million Serbs on the historic battlefield of Gazimestan, 600 years after the Battle of Kosovo. It was the pinnacle, in many ways, of his political life, and he emerged as the symbolic leader of all Serbs. As events would unfold, Kosovo would prove to be for Milošević the source of his rise and also of his ultimate fall (Silber and Little 1996, pp. 42-47; Judah 2002, pp. 50-54; Stephen 2004, pp. 37-39; Human Rights Watch 2006, p. 7).

\section{The path to the courtroom From death to birth}

The SFRY did not survive the passage to the 21st century. Its fairly rapid disintegration began in the 1990s. After the adoption of the new Constitution of Serbia in 1990, Milošević was elected to the newly established Office of the President of Serbia in multi-party elections. One after another, Slovenia, Croatia, and Bosnia and Herzegovina declared their independence from the SFRY. In 1991, the wars in Slovenia (albeit brief) and Croatia began, along with the siege of Vukovar. In 1992, Bosnia followed its neighbours on the road to independence through a referendum and then war, with Sarajevo falling under siege and the setting up of detention camps in April. Relayed through the mass media, these events' dramatic images led to public outcry. Action was demanded (Silber and Little 1996, pp. 37-41; Stephen 2004, pp. 82-85; Human Rights Watch 2006, p. 7). ${ }^{2}$

Later that year, the United Nations Security Council determined under Chapter 7 of the UN Charter that the situation in the former Yugoslavia constituted a threat to international peace and security and passed Resolution 771 , declaring that individuals who committed or ordered the commission of grave breaches of the Geneva Conventions were individually responsible for such breaches and calling on the international community to cooperate in the collection of evidence of those crimes. The Security Council then asked the UN SecretaryGeneral to assemble and task a group of experts to examine this evidence. When the Secretary-General reported back to the Security Council, the Council decided to request him to make a proposal for the establishment of an international criminal tribunal. On 25 May 1993, after having received this proposal, the Security Council acted under Chapter 7 of the UN Charter to pass Resolution 827. Thus was born the ICTY (see generally UNSC Res 827 1993). ${ }^{3}$

As the ICTY was taking its first steps, the armed conflicts in the SFRY continued. In July 1995, the UN Safe Haven at Srebrenica was taken by Bosnian Serb forces, and thousands of Bosnian Muslims were executed. The following month, NATO began to bomb Serb positions, and Croatian forces drove the Serb population from the Krajina. In November, the Dayton Peace Accords were signed by the warring factions, ending the active hostilities in the conflicts (Silber and Little 1996, pp. 265-387; Judah 2002, pp. 109-126; Stephen 2004, pp. 52-76; Human Rights Watch 2006, pp. 7-9).

\section{From bombardment to indictment}

During the conflicts in Croatia and Bosnia, the strategy of the Kosovo Albanian leadership in the Serbian province of Kosovo was one of non-violent civil disobedience. On the other hand, through the police forces of the Serbian Ministry of the Interior (MUP), Belgrade gradually increased its political grip on Kosovo (Judah 2002, pp. 61-98; Human Rights Watch 2006, pp. 9-10). The Democratic League of Kosovo (LDK) was the dominant political party of the Kosovo Albanians and was headed by Ibrahim Rugova, the "President" of the "Republic of Kosova", which had been created on 19 October 1991 when the "parliament" confirmed a 22 September 1991 "Resolution on the Independence and Sovereignty of Kosovo" and subsequent referendum. A parallel government in Kosovo therefore existed alongside the one under the control of Belgrade (Judah 2002, pp. 61-98,109-134).

In July 1997, after having served two terms as President of Serbia, Slobodan Milošević was elected President of the Federal Republic of Yugoslavia (FRY) (ICTY case Information Sheet; Stephen 2004, p. 138). The Kosovo Liberation Army (KLA) became increasingly organised. In 1998, the Serbian forces began a major crackdown on the KLA which, considering the balance of powers, decided to wage a guerrilla war. As the Serbian authorities claimed it was simply rooting out Albanian terrorists, the civilian casualties mounted. When these events were related to the West by the media and also by international observers on the ground in Kosovo, public sentiment was engaged. The concern was to prevent another Bosnia (Judah 2002, pp. 135-163).

Talks between NATO, the Organisation for Security and Co-operation in Europe, Serbs, and the Kosovo Albanians were held on and off throughout 1998 and 1999 but led to few results on the ground. The threat of 
force was used by NATO to little avail. In January 1999, 45 Kosovo Albanians and 9 KLA members were killed in the village of Račak. The circumstances of this incident remain shrouded in mystery to this day. Some called it a legitimate police action to eliminate from the village terrorists who were responsible for an attack on the police a few days earlier. Others characterised it as a massacre. Nevertheless, the NATO countries used Račak and the fact that the Albanian delegation, unlike the Serbs, signed the Rambouillet Agreement, as a major impetus for the use of air strikes against the FRY, which began on March 1999 and continued for 78 days into June (Judah 2002, pp. 193-285; Stephen 2004, pp. 140-145; see also UNSC Res 1244 1999).

On 22 May 1999, during the bombing of Serb positions in Kosovo and various targets in Belgrade itself, ICTY Prosecutor Louise Arbour submitted an indictment against Slobodan Milošević-as well as Milan Milutinović, the President of Serbia; Nikola Šainović, the FRY Deputy Prime Minster; Dragoljub Ojdanić, Chief of the General Staff of the Yugoslav Army (VJ); and Vlajko Stojiljković, the Minister of Internal Affairs of Serbia-for alleged crimes committed in Kosovo (Prosecutor v. Milošević, Milutinović, Šainović, Ojdanić, and Stojiljković 23 May 1999). ${ }^{4}$ On 24 May 1999, Judge David Hunt confirmed the indictment (Prosecutor v. Milošević, Milutinović, Šainović, Ojdanić, and Stojiljković 24 May 1999). ${ }^{5}$ On the same day, a warrant for the arrest of Milošević was issued (Prosecutor v. Milošević 24 May 1999). On 26 May 1999, the ICTY Prosecutor "made her announcement to the world" that Milošević, a serving head of state, was indicted for war crimes and crimes against humanity (Stephen 2004, p. 144).

\section{From elections to detention}

Shortly after Dayton, student protests resumed in 1996 and 1997 (Stephen 2004, p. 156; Judah 2002, p. 306). By the time of the cease fire between NATO and the FRY in June 1999 and the run-up to the federal elections, several political parties were challenging Milošević: the liberal opposition headed by Belgrade's mayor, Zoran Đinđić; the liberal nationalist Serbian Renewal Party, headed by Vuk Drašković; and Vojislav Šešelj of the Radical Party. It has been said that Milošević, amidst continued protests, moved the elections from July 2000 to September 2000 to take advantage of the disorganisation of the opposition (Stephen 2004, pp. 157-158; Judah 2002, p. 306).

Vojislav Koštunica, a law professor considered to be a "compromise candidate", won the election, but Milošević disputed the results. The election commission announced new figures, thus necessitating a second round of voting. Koštunica refused to accept this, and a new flurry of protests ensued (Stephen 2004, p. 159). On 5
October 2000, protestors took the federal parliamentary building, and Milošević finally stepped down from office 2 days later. Koštunica, however, refused to transfer Milošević to the ICTY, citing various legal objections, and announced that Milošević would stay in the presidential palace and be tried in the FRY on corruption charges. In April 2001, Milošević was arrested, removed from the presidential palace, and incarcerated in Belgrade District Prison (Stephen 2004, pp. 160-162; Human Rights Watch 2006, p. 10). It is at this point that the US decided to make monetary aid to the FRY contingent upon Milošević being transferred to The Hague (Stephen 2004, p. 164; Judah 2002, p. 305).

The transfer of Milošević to the United Nations Detention Unit (UNDU) in The Hague is poignantly described by Chris Stephen:

On 28 June 2001, [...] Serbia's cabinet held a special early morning session presided over by prime minister Zoran Djindjić. The Yugoslav President, Vojislav Kostunica, was not informed of the meeting. There was only one item on the agenda and agreement was reached in a matter of minutes. Orders were sent out of the room to the commanders of a police unit which had been briefed on its very special mission the night before. The prison governor was contacted, and he relayed to Milošević the news that he was going to be taken away that evening. [...] At 6 p.m. he was sitting alone in his cell when the prison governor came to tell him to collect his things and prepare to leave. "Where are you taking me?" he asked. "To The Hague," the governor replied.

[...] Instead of a police escort, the governor himself led the former president down the corridor. After going a little way, he stopped and said: "Warden, what's this? It's not right, this is a kidnapping." The governor insisted they keep walking, guiding him through the prison and out into the yard where there was a police van with the back door open. Milošević got in $[\ldots]$.

The transfer was conducted by the police of Serbia, with no involvement of either the Yugoslav federal police or the military which were under the control of President Kostunica. He would later claim that the operation was illegal because only the state has the power to transfer a prisoner out of the country. But Serbia's prime minister, with a billion lifeline at stake, was beyond considering such niceties. Milošević was driven through Belgrade's early morning traffic to a police base with a yard large enough for a helicopter to land. [...] Getting out of the police van, Milošević said: "Well done, you lot, you can take your money now." 
A helicopter was waiting, with two men and one woman, [...] standing by its side door. One of the men was a Hague investigator, the other a Dutch police officer and the woman was a translator. Asked which language he spoke, Milošević replied, "Serbian," and his war crimes indictment was read to him, the interpreter translating from English. This took some time, and Milošević lit a cigarette while he listened. Finally the investigator said: "I am arresting you. You are now under the jurisdiction of the Hague Tribunal." He was helped aboard the helicopter, and someone folded his raincoat and placed it under his seat. He looked up, and called to the pilot and co-pilot: "How are you, lads?" The pilot replied: "All right, Mr President." Milošević turned to the governor and asked: "Warden, where is my raincoat?" These turned out to be his last words on Yugoslav soil (Stephen 2004, pp. 165-167). ${ }^{6}$

Shortly after Milošević was transferred to The Hague and while he was awaiting the commencement of his trial, he passed his 60th birthday in the UNDU. His wife, daughter-in-law, and grandson were granted 3-day visas for the occasion (BBC 2001a, BBC 2001b).

\section{In the courtroom}

ICTY Trial Chambers are composed of three Judges (Statute of ICTY, Art. 12), and until 16 November 2001, the bench in the pre-trial proceedings in the Milošević, which was assigned to Trial Chamber III, consisted of Presiding Judge Richard May, Judge Patrick Robinson, and Judge Mohammed El Habib Fassi Fihri. On 23 November 2001, the President of the ICTY assigned Judge O-Gon Kwon to replace Judge Fassi Fihri, whose term had expired (Prosecutor v. Milošević 23 November 2001a).

The initial appearance of Milošević was a widely watched event and was described by one Senior Legal Officer as such:

On 3 July 2001, the eyes of the world were on Courtroom I of the International Criminal Tribunal for the former Yugoslavia in The Hague. Slobodan Milosevic, the former President of Yugoslavia, was about to make his initial court appearance to enter a plea on charges of war crimes and crimes against humanity in relation to the events in Kosovo during 1998-1999. As the courtroom officials entered promptly, those of us not directly responsible for the conduct of the proceedings felt proud to be part of history in the making. The Chamber of three Judges, presided over by Judge Richard May, entered moments afterwards. In a petulant mood, Slobodan Milosevic refused to acknowledge the authority of the court and, using a tactic that would continue throughout the trial, addressed Judge May as "Mr. May". Later, in response to a question about procedure, he replied tartly: "That's your problem". Judge May refused to rise to the bait, although from my position at the Registry bench, I could picture his raised eyebrow and hear the rhythmic tapping of pen on notebook, the only outward sign of irritation he would ever display (Featherstone 2006, p. 301).

Miloševićs refusal to address the Judges in the customary manner was not the only manifestation of his defiance to the authority and legitimacy of the ICTY. Other examples included refusing to make written filings, although there were exceptions to this refusal, especially during the Defence phase of the case (see, e.g. Prosecutor v. Milošević 8 July 2005, p. 2). ${ }^{7} \mathrm{He}$ also refused to enter pleas of guilty or not guilty to the charges against him during his initial appearance on 3 July 2001 (Prosecutor v. Milošević 3 July 2001b, T.4). Pursuant to Rule 62(A)(iv) of the Rules of Procedures and Evidence ("Rules"), ${ }^{8}$ the Trial Chamber entered pleas of "not guilty" on all counts against him.

\section{The pre-trial phase: testing the waters Self-representation, part I}

At his initial appearance for the Kosovo Indictment on 3 July 2001, Milošević informed the Trial Chamber, both in writing and orally, that he did not want to be represented by a lawyer (Prosecutor v. Milošević 3 July 2001c, Registry pp. 3371-3372; 3 July 2001b, T.1-2). At the first status conference on 30 August 2001, the Trial Chamber noted that Milošević was entitled to represent himself and rejected the Prosecution's suggestion that it should impose defence counsel upon him. According to the Trial Chamber, "the Accused ha[d] a right to counsel, but he also ha[d] a right not to have counsel" (Prosecutor v. Milošević 30 August 2001a, T.15-18). At the time, the health condition of Milošević was not an issue.

\section{Challenging the chamber: appointment of the Amici Curiae and of Legal Associates}

On 31 August 2001, the Trial Chamber issued an order inviting the Registrar of the Tribunal to designate Amicus Curiae. In doing so, the Trial Chamber recognised that, pursuant to Rule $74,{ }^{9}$ the appointment of experienced lawyers to assist Milošević was in the interests of securing a fair trial (Prosecutor v. Milošević 30 August 2001b). The Trial Chamber stated that the purpose of the Amicus Curiae was not to represent an accused who had chosen to defend himself pursuant to Article 21(4)(d) of the Statute but to assist the Trial Chamber in the "proper determination of the case" (Prosecutor v. Milošević 30 August 2001b). Such assistance could take the form of making any submissions 
properly open to Milošević by way of preliminary or other pre-trial motions, making any submissions or objections to evidence properly open to him during the trial proceedings, cross-examining witnesses as appropriate, drawing to the attention of the Trial Chamber any exculpatory or mitigating evidence, and acting in any other way considered appropriate in order to secure a fair trial (Prosecutor v. Milošević 30 August 2001b, p. 2).

On 6 September 2001, the Registrar appointed three lawyers to act as Amici Curiae. ${ }^{10}$ One of their main functions was to prepare out-of-court written submissions, whereas two of them would be more involved with the day-to-day proceedings of the trial, both in and out of court. ${ }^{11}$ The Registrar was directed to provide to the Amici Curiae all information, including confidential, that was provided to Milošević (Prosecutor v. Milošević 19 September 2001).

The role of the Amici Curiae in the Milošević case was innovative in that they functioned, in practical terms, as stand-by counsel to a pro se accused. They were seated in court on a daily basis, although not directly at the bench where defence counsel would normally sit. Due to the fact that Milošević refused to make written filings, including responding to Prosecution motions for the admission of evidence, the Amici Curiae regularly made written filings opposing these Prosecution motions, much like a defence counsel would. They adopted a role of identity of interest with Milošević and did not assume the role of disinterested third parties appointed to assist the Chamber only-although the positions they adopted in their oral and written submission were aimed at ensuring the fairness of the proceedings, from their own professional point of view.

On 15 November 2001, the Trial Chamber issued an order on Milošević's request for the Registry to permit him to meet with two lawyers to assist him. The Chamber ordered that the two men would be considered to be "legal advisors" to Milošević. ${ }^{12}$ The Trial Chamber also ordered that Milošević would be entitled to communicate fully and without restraint with them in accordance with Rule 65 of the ICTY Rules of Detention (Prosecutor v. Milošević 15 November 2001). ${ }^{13}$ In other words, Milošević would enjoy attorney-client privilege with his two Legal Associates.

The role of the Legal Associates throughout the proceedings was a significant one, even though they were never seen within the courtroom and even though, in general, they did not make written filings on behalf of Milošević during the proceedings.

\section{Challenging the ICTY: jurisdiction and legality}

In August 2001, Milošević filed two motions challenging the jurisdiction and legality of the ICTY (Prosecutor v. Milošević, Milutinović, Šainović, Ojdanić, and Stojiljković
9 August 2001; 30 August 2001), which were supplemented by the Amici Curiae (Prosecutor v. Milošević 16 August 2001; 19 October 2001; 13 September 2001). On 8 November 2001, the Trial Chamber issued its written decision (Prosecutor v. Milošević 8 November 2001). ${ }^{14}$ In rejecting the motions, the Trial Chamber considered several issues.

The Amici Curiae and Milošević challenged the legality of the ICTY by arguing that the UN Security Council was not empowered to establish an international criminal court. The Trial Chamber noted, however, that Article 41 of the UN Charter empowered the Security Council to adopt measures to meet its obligation to maintain or restore international peace and security. As stated by the Trial Chamber in its decision:

The relevant provision is Article 41 of the Charter, which empowers the Security Council to adopt measures not involving the use of armed force to give effect to its decisions in order to discharge its obligation under Article 39 to maintain or restore international peace and security. Article 41 lists certain measures which may be taken by the Security Council. It is perfectly clear that the list is not exhaustive and that it is open to the Security Council to adopt any measure other than those specifically listed, provided it is a measure to maintain or restore international peace and security.

... In the Chamber's view, the establishment of the International Tribunal with power to prosecute persons responsible for serious violations of international humanitarian law in the former Yugoslavia, and with the obligation to guarantee fully the rights of the accused, is, in the context of the conflict in the country at that time, pre-eminently a measure to restore international peace and security. Indeed, the role of the International Tribunal in promoting peace and reconciliation in the former Yugoslavia is highlighted in Security Council resolution 827 which established it. The Appeals Chamber in the Tadic Jurisdiction Appeal arrived at the same conclusion and concluded that "the establishment of the International Tribunal falls squarely within the powers of the Security Council under Article 41" (Prosecutor v. Milošević 8 November 2001, paras. 6-7).

Second, Milošević argued that the creation of an ad hoc tribunal with a focus on violations of international law in one country targeted that country, corrupted justice and law, and violated the most basic legal principles. Nevertheless, the Trial Chamber noted that the Appeals Chamber had held that ad hoc tribunals, and the ICTY in particular, were permissible so long as they afforded 
Milošević all the guarantees of a fair trial, as set out in Article 14 of the International Covenant on Civil and Political Rights. In this regard, the Trial Chamber noted that Article 21 of the Statute afforded substantially the same rights as Article 14 of the Covenant (Prosecutor v. Milošević 8 November 2001, paras. 9-10). ${ }^{15}$

Third, the Amici Curiae impugned the independence of the Prosecutor. In 1998, the Security Council urged the Office of the Prosecutor "to begin gathering information related to the violence in Kosovo that may fall within its jurisdiction". The Amici Curiae argued in their brief that the Prosecutor lacked independence and had thus violated Article 16(2) of the Statute. The Trial Chamber held, however, that initiating an investigation at the behest of another is not indicative of a lack of independence. A lack of independence would exist where the assessment of evidence and the decision whether to indict an individual were based on someone else's instructions. Since there was no suggestion that the Prosecutor had acted upon the instruction of any government, body, or any other person in her decision to indict Milošević, there was no failure of independence and thus no violation of the Statute (Prosecutor v. Milošević 8 November 2001, paras. $12-17) .^{16}$

Fourth, there was an allegation of bias. The Amici $\mathrm{Cu}$ riae contended that the ICTY was incapable of providing Milošević with a fair trial or of protecting his fundamental rights (Prosecutor v. Milošević 19 October 2001, pp. 7-8). Milošević argued that the "very psychology of the enterprise is persecutorial" (Milošević Motion 30 August 2001, pp. 7-8). The Trial Chamber construed these arguments as an allegation of bias on the part of the ICTY and of the Trial Chamber itself. The Trial Chamber considered a decision of the Appeals Chamber according to which there were three means of establishing bias and found that only one was relevant in the instant case: the test whether a reasonable observer, properly informed, would reasonably apprehend bias. The Trial Chamber dismissed the argument since neither the Amici Curiae nor Milošević had met this test (Prosecutor v. Milošević 8 November 2001, paras. 18-22). ${ }^{17}$

Fifth, the Amici Curiae contended that the ICTY lacked jurisdiction over Milošević because of his status as the former President of the FRY. Article 7(2) of the Statute provided, "The official position of any Accused person, whether as Head of State or Government ... shall not relieve such person of criminal responsibility nor mitigate punishment" (Statute of ICTY, Art. 7(2)). The Trial Chamber therefore held that there was no basis for challenging this Article, "which at this time reflects a rule of customary international law" (Prosecutor v. Milošević 8 November 2001, paras. 26-34).
Finally, the Amici Curiae argued that the ICTY lacked jurisdiction because Milošević was surrendered unlawfully: it was the government of Serbia that surrendered him, even though the arrest warrant was directed to the FRY (Prosecutor v. Milošević 19 October 2001, para. 15). The Amici Curiae also argued that, since the FRY did not allow extradition of its citizens, the transfer of Milošević was an abuse of process because the internal procedures of the FRY had not been followed. In rejecting this challenge, the Trial Chamber relied on Rule 58, which provided that "the obligations laid down in Article 29 of the Statute (which requires the cooperation of all States) shall prevail over any legal impediment to the surrender or transfer of the Accused ... which may exist under the national law or extradition treaties of the State concerned" (Prosecutor v. Milošević 19 October 2001, paras. $35-51) .^{18}$

With Milošević's challenges to the jurisdiction of the Tribunal to try him dismissed, the proceedings now focused on preparing the case for trial.

\section{Scope of the indictments \\ The three indictments: Croatia, Bosnia, and Kosovo}

Milošević was initially indicted along with other highlevel military and political leaders of the FRY and Serbia for the events in Kosovo in the summer of 1999. On 5 September 2002, the Trial Chamber severed Milošević's trial from that of his co-accused, so that he could be tried separately (Prosecutor v. Milošević, Milutinović, Šainović, Ojdanić, and Stojiljković 5 September 2002). ${ }^{19}$ Milošević would be the subject of a trial devoted solely to him, and his indicted associates would have to wait another 4 years before their trial would even begin. ${ }^{20}$

On 29 October 2001, via an oral decision, the Trial Chamber granted leave to amend the Kosovo Indictment, confirming that the Second Amended Indictment was the operative indictment for the Kosovo phase of the proceedings (Prosecutor v. Milošević, Milutinović, Šainović, Ojdanić, and Stojiljković 29 October 2001). ${ }^{21}$ In that indictment, Milošević was charged pursuant to Article 7(1), individual criminal responsibility, and Article 7(3), superior criminal responsibility, with murder, as a violation of laws or customs of war, and with four crimes against humanity: deportation, other inhumane acts (forcible transfer), murder, and persecution on political, racial, and religious grounds.

In the autumn of 2001, following the election of Carla Del Ponte as the new ICTY Prosecutor, Judge Almiro Rodrigues confirmed the initial Croatia Indictment against Milošević and Judge Richard May confirmed the Bosnia Indictment against him (Prosecutor v. Milošević 8 October 2001; 22 November 2001). Both cases were subsequently assigned by the President of the ICTY to 
Trial Chamber III (Prosecutor v. Milošević 9 October 2001; 23 November 2001b).

On 29 October 2001 (Motion Hearing 29 October 2001, T.123) and 11 December 2001 Hearing, 11 December 2001, T. 32 (Bosnia), Milošević made his initial appearances on the Croatia and Bosnia indictments. Just as with the Kosovo Indictment, Milošević refused to enter pleas of guilty or not guilty.

These new indictments alleged that, from 1991 to 1995, Milošević was responsible for the furnishing of aid and support to the Serb populations during the armed conflicts in Croatia and Bosnia and plotted with the Serb leaders in those countries to secure Serb control over as much territory as possible. The means by which this was to be accomplished, as alleged by the Prosecution, was the killing, torture, rape, and forcible displacement of the non-Serb populations. Milošević was charged with grave breaches of the Geneva Conventions of 1949, violations of the laws or customs of war, crimes against humanity, and, in Bosnia, genocide.

More specifically, in the Croatia Indictment, Milošević was charged pursuant to Article 7(1), individual criminal responsibility, and Article 7(3), superior criminal responsibility, with:

Article 2, Grave Breaches of the Geneva Convention of 1949: nine counts of wilful killing; unlawful confinement; torture; wilfully causing great suffering; unlawful deportation or transfer; and extensive destruction and appropriation of property not justified by military necessity and carried out unlawfully and wantonly

Article 3, Violations of laws or customs of war: 13 counts of murder; torture; cruel treatment; wanton destruction of villages or devastation not justified by military necessity; destruction or wilful damage done to institutions dedicated to education or religion; plunder of public or private property; attacks on civilians; destruction or wilful damage done to historic monuments and institutions dedicated to education or religion; and unlawful attacks on civilian objects

Article 5, Crimes against humanity: ten counts of persecution on political, racial, or religious grounds; extermination; murder; imprisonment; torture; inhumane acts; deportation; and inhumane acts (forcible transfers) ${ }^{22}$

As for the Bosnia Indictment, Milošević was charged pursuant to Article 7(1), individual criminal responsibility, and Article 7(3), superior criminal responsibility, with:

Article 2, Grave Breaches of the Geneva Convention of 1949: eight counts of wilful killing; unlawful confinement; torture; wilfully causing great suffering; unlawful deportation or transfer; and extensive destruction and appropriation of property not justified by military necessity and carried out unlawfully and wantonly
Article 3, Violations of laws or customs of war: nine counts of murder; torture; cruel treatment; wanton destruction of villages or devastation not justified by military necessity; wilful destruction or wilful damage done to historic monument and institutions dedicated to education or religion; plunder of public or private property; and attacks on civilians

Article 4, Genocide: two counts of genocide and complicity in genocide.

Article 5, Crimes against humanity: ten counts of persecutions on political, racial, or religious grounds; extermination; murder; imprisonment; torture; inhumane acts; deportation; and inhumane acts (forcible transfer)

Milošević was facing three massive indictments spanning three armed conflicts in the 1990s. What was to occur next-the joinder of the indictments-affected the course of the remainder of the proceedings.

\section{Joinder of the indictments}

On 27 November 2001, the Prosecution filed a motion for joinder pursuant to Rule 49, in which it sought to join the three indictments against Milošević into a single trial (Prosecutor v. Milošević, Milutinović, Šainović, Ojdanić, and Stojiljković 27 November 2001; Motion for Joinder 10 December 2001).

The Prosecution asserted that the following considerations supported its motion for joinder. First, it referred to Rule 49 , which provided that, "[t]wo or more crimes may be joined in one indictment if the series of acts committed together form the same transaction, and the said crimes were committed by the same accused" (Rule 49 of the Rules, IT/32/Rev. 2110 December 2009). A "transaction" for these purposes was defined in Rule 2 as a "number of acts or omissions, whether occurring as one event or a number of events, at the same or different locations and being part of a common scheme, strategy or plan" (IT/32/Rev.44 10 December 2009). The Prosecution therefore argued that the three indictments concerned the same transaction in the context of a common scheme, strategy, or plan because Milošević's overall conduct in attempting to create "a centralised Serbian state encompassing the Serb-populated areas of Croatia and Bosnia and Hercegovina, and all of Kosovo" (Prosecutor v. Milošević, Milutinović, Šainović, Ojdanić, and Stojiljković 27 November 2001, p. 5). The Prosecution called the Trial Chamber's attention to paragraph 6 of the Croatia Indictment, paragraph 6 of the Bosnia Indictment, and paragraph 16 of the Kosovo Indictment, all of which alleged the forcible removal of non-Serbs from the territories in question. The Prosecution also argued that joinder of the three indictments would lead to a more fair and expeditious trial for Milošević. In the 
view of the Prosecution, a single trial would be shorter and would provide a more consolidated trial timetable (Prosecutor v. Milošević 27 November 2001, p. 4). Without joinder, Milošević would be litigating one trial, while simultaneously confronting two pre-trial phases (Prosecutor v. Milošević 27 November 2001, p. 15). Moreover, having three trials instead of one would require repeated testimony, and different trial chambers would have to consider the degree to which evidence or findings from one trial needed be incorporated into another (Prosecutor v. Milošević 27 November 2001, p. 15). The Prosecution further argued that a single trial would promote judicial economy (Prosecutor v. Milošević 27 November 2001, pp. 15-18). For example, witnesses testifying on history or policy would not have to give evidence three times (Prosecutor v. Milošević 27 November 2001, p. 17). The Prosecution also submitted that the trauma to victims would be lessened if they only needed to testify once (Prosecutor v. Milošević 27 November 2001, p. 18), and security concerns would be fewer if the witnesses only had to travel to the ICTY once (Prosecutor v. Milošević 27 November 2001, p. 18). Finally, the Prosecution maintained that a single trial would avoid inconsistency. In a joint trial, the same Trial Chamber would be deciding issues of credibility and evaluating the evidence and therefore would have a better chance of avoiding conflicting factual findings (Prosecutor v. Milošević 27 November 2001, pp. 18-19). A single trial would also obviate concern about the appeal of one trial judgment on the merits, while the second or third trial was still ongoing (Prosecutor v. Milošević 27 November 2001, pp. 18-19).

In their response, the Amici Curiae noted that Milošević did not recognise the ICTY and that there were therefore no issues for the Amici Curiae to submit on this issue on his behalf (Prosecutor v. Milošević 5 December 2001, p. 6). However, the Amici Curiae did point out that the Trial Chamber would have to consider the extreme scale of the single trial exercise and whether the Chamber was able adequately to deal with it (Prosecutor v. Milošević 5 December 2001, p. 6).

On 11 December 2001, having heard oral arguments from both parties and the Amici Curiae (Motion Hearing 11 December 2001, T68 et seq), the Trial Chamber gave its oral decision. The Chamber decided to join the Croatia and Bosnia indictments, but refused to join the Kosovo case with the others. In addition, the Kosovo case would be heard first, with the joint Croatia and Bosnia trial following later (Motion Hearing 11 December 2001, T.145). Two days later, the Trial Chamber issued its written decision on joinder (Prosecutor v. Milošević 13 December 2001). The Trial Chamber held that the essence of the test under Rule 49 on joinder was the determination of whether a "series of acts, committed together, formed the same transaction" or was a part of a common scheme, strategy, or plan and that, in exercising its discretion under the Rule, it had taken into account the entitlement of an accused to a fair hearing under Article 21(2) of the Statute; the interests of justice, which related to the accused as well as to the interests of the Prosecution and the international community in the trial of any accused charged with serious violations of international humanitarian law; and judicial economy, such as the avoidance of duplication of evidence and the avoidance of hardship to witnesses (Prosecutor v. Milošević 13 December 2001, paras. 28, 38-40).

The Prosecution was not satisfied with this decision and sought review before the Appeals Chamber.

The Appeals Chamber reversed the decision of the Trial Chamber. On 1 February 2002, the Appeals Chamber ordered that the three indictments against Milošević be tried together in one trial (Prosecutor v. Milošević 1 February 2002). On 18 April 2002, the Appeals Chamber issued its reasons. It held that Rule 49 did not require that the events in Kosovo were committed together with the events in Croatia and Bosnia in order for all the trials to be joined (Prosecutor v. Milošević 18 April 2002). In other words, a common scheme, strategy, or plan could include the achievement of a long-term aim which, in the case of Milošević, was the forcible removal of the majority of the non-Serb civilian population from areas that the Serb authorities wished to establish (Prosecutor v. Milošević 18 April 2002, paras. 14, 20). Thus, Milošević would face 66 counts of genocide, crimes against humanity, and war crimes in a consolidated indictment of an unprecedented scope and size.

However, to say that Milošević was facing 66 counts does not adequately capture the size and scope of the case against him (see Additional file 1). ${ }^{23}$ At the Tribunal, "counts" are simply a textual means by which the Prosecution organises "charges" in a written indictment. A charge is the vehicle by which the Prosecution alleges that an accused is responsible for a crime. In the indictments, a single count often referred to crimes in dozens of municipalities, cross-referenced to schedules attached to the indictment. In addition, the same factual scenarios are often charged under multiple counts. This all resulted in a gargantuan puzzle of charges, which can be estimated between 5000 and 6000 individual charges, each of which exposed Milošević to criminal responsibility.

The size and scope of each of the indictments were daunting. Now that they were to be tried together, the situation became even more pronounced.

An early estimate of the trial-which was provided at the status conference of 30 October 2001-predicted that, if the three indictments were to be tried together, the Prosecution case would require approximately 
500 days (Prosecutor v. Milošević 30 October 2001, T.53). Taking into account the time the Defence would need to present its case, the total time for the trial was estimated to take at least 3 years (Prosecutor v. Milošević 30 October 2001, T.53). The Prosecution clarified in the motion hearing of 11 December 2001 that the estimated length of the trials, if separate, were in the range of 13 months for Bosnia, 10 months for Croatia, and 9 months for Kosovo (Prosecutor v. Milošević 11 December 2001, T.99). Although the Prosecution averred that the joint trial would mean an overall savings of time (Prosecutor v. Milošević 11 December 2001, T.99), the scope of the evidence it would seek to adduce was massive.

The number of witnesses anticipated for all three indictments was estimated early on to be approximately 600 (Motion Hearing 11 December 2001, T.89). It was clarified later by the Prosecution during a hearing on 11 December 2001 that the number of witnesses for all three indictments would be 300 (Motion Hearing 11 December 2001, T.97).

\section{The trial: no plain sailing}

The prosecution's case-in-chief

Notwithstanding the scope and size of the case, the pretrial phase, which lasted only 7 months, was relatively brief, and the trial commenced on 12 February 2002 (Prosecutor v. Milošević 4 February 2002).

\section{Length of Prosecution case}

On 10 April 2002, the Trial Chamber issued, proprio $m o t u$, an oral decision directing the Prosecution to conclude its case, subject to "the unexpected" events such as illness or other unforeseen circumstances, within 12 months. This was in addition to the 2 months it had already used. The Trial Chamber expressed the view that the Prosecution case should not continue for more than 14 months in total (Hearing 10 April 2002, T. 2784 et seq). Six days later, the Prosecution requested leave to file an interlocutory appeal of this order pursuant to Rule 73(D). ${ }^{24}$ It argued that the Trial Chamber had invaded the independence of the Prosecutor provided for in Article 16(2) of the Statute (Prosecutor v. Milošević 16 April 2002a). ${ }^{25}$

On 25 April 2002, the Appeals Chamber issued its decision. It held that, even if Rule 73(D) had been applicable in this case, the Chamber was not satisfied that the conditions for its application had been met (Prosecutor v. Milošević 25 April 2002a). On 16 May 2002, the Appeals Chamber issued its legal reasons. It held that every court possesses the inherent power to control the proceedings during the course of the trial and that the Trial Chamber, in limiting the time that the prosecution had to present its case, had not interfered with the independence of the Prosecution (Prosecutor v. Milošević 16 May 2002). ${ }^{26}$

\section{Evidentiary matters}

The sheer scale of the case led to experiments in procedural mechanisms that would allow the trial to be completed within reasonable parameters. Most of these innovations related to reducing the amount of time in court that was required for the admission of evidence.

Admission of evidence under Rule 92 bis Rule 92 bis had been adopted in 2000 by the judges of the Tribunal in order to provide a vehicle for the admission of evidence in lieu of oral testimony, when certain conditions were met. ${ }^{27}$ Whether this rule was to be applied in the Milošević trial was a matter that was litigated by the parties early on in the Kosovo phase of the case.

After having heard the parties, the Trial Chamber decided to admit the written evidence of many witnesses relevant to the Kosovo case. In doing so, the Trial Chamber stated,

The Kosovo Indictment expressly states that the Prosecution does not intend to suggest that the accused committed any of the crimes charged personally in a physical sense. The phrase "acts and conduct of the accused" in Rule 92bis is a plain expression and should be given its ordinary meaning: deeds and behaviour of the accused. It should not be extended by fanciful interpretation. No mention is made of acts and conduct by alleged co-perpetrators, subordinates or, indeed, of anybody else. Had the rule been intended to extend to acts and conduct of alleged co-perpetrators or subordinates it would have said so. The fact that conduct is that of co-perpetrators or subordinates is relevant to whether cross-examination should be allowed and not to whether a statement should be admitted. Consequently, having examined the 23 written statements, the Trial Chamber finds that the statements go to proof of matters other than the acts and conduct of the accused (Prosecutor v. Milošević 21 March 2002, para. 22).

The holding of the Trial Chamber set the standard in ICTY jurisprudence for what "acts and conduct" means under Rule 92 bis. The Trial Chamber then went on to require cross-examination of the witnesses because

[a]nalysis of the statements reveals that all relate to alleged attacks by Serb forces on Kosovo municipalities and the resulting deportations and killings. The accused has put this evidence into issue and vigorously put forward a contrary case. There is, therefore, an important issue for the Trial Chamber to try. The evidence relates to a "critical element of the 
Prosecution's case" or, put another way, to a live and important issue between the parties, as opposed to a peripheral or marginally relevant issue (Prosecutor v. Milošević 21 March 2002, para. 24).

Judge Robinson issued a concurring opinion, expressing his view that, once a trial chamber determines that the evidence goes to a "critical element" of the Prosecution case, the chamber does not have discretion to admit the evidence without allowing the accused to crossexamine the witness (Prosecutor v. Milošević 21 March 2002). ${ }^{28}$

The Trial Chamber would again take up these issues when it dealt with a Prosecution motion to admit written evidence in lieu of oral testimony in relation to a crime site in Foča, Bosnia. On 10 January 2003, the Prosecution requested the admission of transcripts and accompanying exhibits of evidence given by 11 witnesses who previously testified in the Krnojelac and Kunarac cases in lieu of viva voce evidence. The Prosecution also sought an order that the transcripts be admitted without cross-examination, as Rule 92 bis permitted under paragraph (E). The Prosecution submitted that the evidence dealt exclusively with crime-base events alleged to have occurred in the Foča municipality and not with the acts and conduct of the accused or a critical element of the case. On 28 April 2003, the Trial Chamber heard oral arguments on the motion and on 8 May 2003 rendered an oral ruling. On 30 June 2003, the Trial Chamber issued its written decision on the motion, holding that the right of an accused to examine, or have examined, witnesses against him is not an absolute one (Prosecutor v. Milošević 30 June 2003, para. 24).

The Trial Chamber decided to admit several of the transcripts without requiring the witnesses to appear for cross-examination. It did so because the evidence was purely "crime base" evidence relating to the takeover of a municipality and, as such, did not involve such a critical element or important issue as to require further crossexamination. In so far as it related to an issue between the parties, it was not of such a nature that it could not be adequately covered by cross-examination in the earlier proceedings. The Trial Chamber also found that the crossexaminations in the earlier proceedings were undertaken on behalf of an accused with a substantially common interest to serve as Milošević, namely to oppose and contest the evidence about the takeover of Foča and to question the credibility of the witnesses. Finally, the Trial Chamber accepted the Prosecution submission that the cross-examination in the previous cases was adequate, although observing that "quantity is not a measure of the quality of cross-examination" and that "the measurement of adequacy cannot be calculated to a nicety" (Prosecutor v. Milošević 30 June 2003, paras. 39-42).
In respect of the some of the witnesses, the Trial Chamber also noted that it would be unreasonable to insist upon their return to the Tribunal to give evidence again. Several of the witnesses were the victims of multiple rapes, and further cross-examination would run the risk of re-traumatisation. The Chamber held,

Cross-examination should not be permitted mechanically and as a matter of course. Where the rights of the accused are protected, as in this case, by earlier cross-examinations, the balance, as here, should be struck on the side of the victims and witnesses (Prosecutor v. Milošević 30 June 2003, paras. 46-48).

The Chamber made it clear that, in circumstances where issues arise later in the trial that called into question aspects of the testimony given in prior proceedings, the witness could be called and subjected to cross-examination (Prosecutor v. Milošević 30 June 2003, para. 49).

Judge Robinson did not agree with the majority's decision to admit the transcripts without giving Milošević the opportunity to cross-examine the witnesses. He expressed his position in a lengthy dissenting opinion. According to Judge Robinson,

[t]he faculty for a Trial Chamber to determine that cross-examination in a previous trial is adequate such that cross-examination in an ongoing case may be dispensed with is, in my view, unduly intrusive in relation to the right of an accused person to determine his own defence in a system that, despite innovative procedures drawn from the civil law inquisitorial system, remains essentially adversarial. The intrusiveness of this role may upset the balance between the two legal systems on which the Tribunal's sui generis legal system is built (Prosecutor v. Milošević 30 June 2003, para. 40).

Judge Robinson ultimately concluded that, in all the circumstances, a decision to admit the transcripts without requiring the witnesses to appear for crossexamination resulted in a procedure that achieved expeditiousness at the expense of fairness and thus was in breach of Articles 20 and 21 of the Statute (Prosecutor v. Milošević 30 June 2003, para. 44(vi)).

Admission of evidence under Rule 89(F) In addition to the time-saving procedural mechanisms of Rule 92 bis, the Prosecution responded to the time constraints placed upon it by attempting to find innovative procedural methods of introducing evidence that would utilise the least time possible during court hearings. The new modalities in fact enabled the Prosecution to introduce 
huge amounts of evidence in writing, rather than leading it viva voce from witnesses on the stand. Although the Trial Chamber disagreed with some of the appropriateness of these methods, it granted certification of interlocutory appeals in order to ensure that the Appeals Chamber set right any errors it had made. This is, in fact, what happened in respect of the Prosecution's attempts to utilise Rule 89(F) in such a manner.

Rule 89(F) provided that, "[a] Chamber may receive the evidence of a witness orally or, where the interests of justice allow, in written form." The provision had been amended in December 2000 in order to modify the principle of orality that had been there before. At the same time as this amendment, the Judges adopted Rule 92 bis in order to deal with the admission of a special kind of hearsay evidence, witness statements and transcripts from previous trials that did not go to the acts and conduct of the accused. However, there were strict attestation requirements connected to the admission of such evidence, with which the Prosecution wished to dispense. The Prosecution argued that statements of a witness, made at any time and not in accordance with the attestation requirements, were nevertheless subject to admission under Rule 89(F), provided that the witness was available to attest on the stand that the statement was in fact his and was available for cross-examination.

In April 2003, the Trial Chamber denied a Prosecution motion to submit the evidence-in-chief of some of its witnesses in writing, without the need to fulfil the attestation requirements of Rule 92 bis (Prosecutor v. Milošević 16 April 2003). The Trial Chamber held in its written decision that "under the present Rules, such written statements are only admissible under Rule 92 bis and by no other means" (Prosecutor v. Milošević 16 April 2003, p. 2). ${ }^{29}$ In May 2003, the Trial Chamber certified an interlocutory appeal of its decision (Prosecutor v. Milošević 6 May 2003a). In September 2003, the Appeals Chamber issued its decision on the matter. It held that, where the witness was present before the Trial Chamber and orally attested to the accuracy of his or her statement, the evidence entered into the record could not be considered to be exclusively "written" within the meaning of Rule 92 bis. The Appeals Chamber explained that the testimony of a witness constituted a mixture of oral and written evidence and that the appearance of the witness in court to attest to a written statement was a crucial factor that rendered Rule 92 bis inapplicable. According to the Appeals Chamber, the fact that there should be greater safeguards when the evidence relates to the acts and conduct of the accused was a factor that a Trial Chamber could take into account in determining whether to admit written evidence under Rule $89(\mathrm{~F})$ or what weight to attach to the evidence. Nonetheless, "the appearance of the witness in court to orally attest to the accuracy of the tendered statement is an important safeguard in itself because the witness is certifying the accuracy of the statement before the Court and is available to answer questions from the bench" (Prosecutor v. Milošević 20 September 2003, paras. 16, 19).

The Appeals Chamber thus allowed the appeal because, as a matter of law, the Rules allowed for the admission of a written witness statement under Rule 89(F) when the witness was present in court, was available for cross-examination and any questioning by the judges, and attested that the statement accurately reflected his or her declaration and what he or she would say if examined. The Appeals Chamber returned the matter to the Trial Chamber for action in accordance with its decision. The Trial Chamber subsequently admitted witness statements under Rule 89(F) so long as the information therein did not go to Miloševićs acts and conduct. ${ }^{30}$

The jurisprudence of the Appeals Chamber in this interlocutory decision was later codified in a newly adopted Rule-Rule 92 ter. This Rule quickly became-and remains to this day-the standard manner in which the majority of witnesses' evidence was admitted in the Tribunal's cases, thereby reducing the time needed to lead evidence from witnesses on the stand. It is now rare for the Tribunal to hear from "pure" viva voce witnesses, and even witnesses who appear in court to give evidence usually have prior statements or transcripts admitted into evidence along with their in-court testimony, a phenomenon that has come to be known as "hybrid witnesses".

Rule 92 ter has also been adopted verbatim by the Judges of the International Residual Mechanism for Criminal Tribunals, the successor of the ICTY and the International Criminal Tribunal for Rwanda (ICTR), as Rule 111 (MICT/1 2012). This procedural innovation will therefore be available for any trials conducted by the Mechanism of ICTR fugitives, persons accused of contempt before the Mechanism, and any re-trials ordered by the Appeals Chamber.

\section{Admissibility of investigator's summary evidence The} Prosecution also attempted to admit evidence in the form of a summary by an investigator. On 30 May 2002, the Trial Chamber rejected the admission into evidence of a summary of witness statements and other material related to events alleged to have taken place in Račak, which had been prepared by an investigator of the Prosecution (Hearing 30 May 2002, T.5940-5944). In so deciding, the Chamber first referred to an earlier decision it had rendered in relation to evidence that the Prosecution had proposed to be given by one of its investigators who, after reading a series of witness statements, had come to various conclusions. The Chamber 
had excluded the evidence on the ground that "it was hearsay evidence of no probative value, which amounted to no more than a repetition of the Prosecution case" (Hearing 30 May 2002, T.5941, referring to Hearing, T.672-673).

With this prior ruling in mind, the Chamber held:

A further reason may be given for excluding this type of evidence, at least in relation to the conclusions of the witnesses. That is that for a witness to give his or her conclusions upon the evidence is to trespass on the function of the Trial Chamber. It is for the Trial Chamber to decide which evidence to accept and which to reject and what conclusions to draw from the evidence. Therefore, any evidence which trespasses on those functions is normally to be excluded (Hearing 30 May 2002, T.5941-5942).

The Prosecution appealed the decision of the Trial Chamber, and the Appeals Chamber dismissed the appeal (Prosecutor v. Milošević 30 September 2002).

Adjudicated facts In another attempt to admit evidence in the case using the least amount of time in court, the Prosecution tested the limits of a trial chamber's ability to take judicial notice of adjudicated facts pursuant to Rule 94. Paragraph (B) of this Rule provided that, "[a]t the request of a party or proprio motu, a Trial Chamber, after hearing the parties, may decide to take judicial notice of adjudicated facts or documentary evidence from other proceedings of the Tribunal relating to matters at issue in the current proceedings."

On 25 April 2002, the Prosecution filed a motion, pursuant to Rule 94(B), requesting that the Trial Chamber take judicial notice of facts related to events that occurred in the municipality of Brčko (Prosecutor v. Milošević 25 April 2002b). ${ }^{31}$ On 5 June 2002, the Trial Chamber issued its decision, holding that for a fact to be capable of admission under Rule 94(B), it should be truly adjudicated and not based on an agreement between parties to previous proceedings, such as agreed facts underpinning a plea agreement (Prosecutor v. Milošević 5 June 2002). Several months later, the Prosecution requested that the Trial Chamber take judicial notice of facts derived from four cases that had been the subject of a final judgement on appeal: Prosecutor v. Tadić, Prosecutor v. Delalić et al., Prosecutor v. Kupreškić et al., and Prosecutor v. Kunarac et al..$^{32}$ In April 2003, the Trial Chamber rendered its decision, in which it admitted some of the facts in question while rejecting others on the basis that they could have been the subject of "reasonable dispute" (Prosecutor v. Milošević 10 April 2003). Later in that month, the Trial Chamber granted the Prosecution's request for certification of an interlocutory appeal of that decision. In October 2003, the Appeals Chamber "returned the matter to the Trial Chamber for it to review the taking of judicial notice of the adjudicated facts" (Prosecutor v. Milošević 28 October 2003).

On 6 November 2003, the Trial Chamber asked the parties and Amici Curiae to make submissions on the effect of the Appeals Chamber ruling (Prosecutor v. Milošević 6 November 2003). The Amici Curiae submitted that the Prosecution should be put to the task of persuading the Trial Chamber that a revised and less extensive list of facts could be admitted without compromising the right of Milošević to a fair trial (Prosecutor v. Milošević 18 November 2003). The Prosecution adhered to its initial application (Prosecutor v. Milošević 26 November 2003).

In December 2003, the Trial Chamber issued another decision on this matter. It held that the admission of adjudicated facts on a wholesale basis would raise the possibility of placing a heavy burden upon Milošević in the preparation and conduct of his case. The Trial Chamber was also concerned that attempts by Milošević to rebut these facts could absorb considerable time and resources during the course of the proceedings, thereby undermining judicial economy and expeditiousness (Prosecutor v. Milošević 16 December 2003a). The Trial Chamber admitted some of the facts set out by the Prosecution, relating to Foča and Prijedor, and decided that they could be challenged by Milošević.

Admission of intercepted communications In September 2002, during the course of a witness's testimony, the Prosecution indicated that it wished to admit an intercepted conversation as evidence. Milošević objected, arguing that the conversation was obtained illegally and that "anything that is illegal can be introduced" (Hearing 27 September 2002, T.10389). Later, the Trial Chamber heard oral submissions from Milošević. He did not contest that all the recordings were made on the territory of Bosnia and was not challenging the authenticity of the recordings at this stage but argued that all recordings were intercepted illegally without the authority of the state agency in-charge (Hearing 30 September 2002, T.10412). In October, the Prosecution filed its response, requesting that the Trial Chamber admit into evidence a number of intercepted communications concerning the Bosnia phase of the trial (Prosecutor v. Milošević 31 October 2002). On 19 November and 10 December 2002, the Trial Chamber held further hearings.

Thereafter, a number of intercepted communications were led through different witnesses, including a witness who was called to verify the procedure and authenticate all the intercepts. In all, 245 intercepts were marked for identification, pending admission into evidence. The Trial Chamber then turned to the task of deciding the 
admission of these intercepts into evidence. On 16 December 2003, the Trial Chamber admitted the 245 intercepts into evidence on a prima facie basis and reserved its final ruling with respect to admissibility subject to a determination of the relevance and reliability of the intercepts (Prosecutor v. Milošević 16 December 2003b). Upon the Trial Chamber's request, the Prosecution submitted on 19 January 2004 its analysis (with respect to relevance and reliability), and the Amici Curiae on 16 February 2004 identified 15 intercepts to be assessed for their authenticity by a court-appointed expert. The court-appointed expert found that the intercepts were substantially complete and that there was no evidence that they had been tampered with. In June 2004, the Trial Chamber issued its decision, holding that some of the intercepts were relevant and some were not and admitting the ones that were (Prosecutor v. Milošević 14 June 2004, p. 3).

Rule 70: conditions placed upon evidence by states Rule 70(B) provides that, if the Prosecution is in possession of information that has been provided to the Prosecutor on a confidential basis and used solely for the purpose of generating new evidence, that initial information and its origin shall not be disclosed by the Prosecution without the consent of the person or entity providing the initial information and shall in any event not be given in evidence without prior disclosure to the accused. ${ }^{33}$ Paragraph (C) of Rule 70 provides that, if, after obtaining the consent of the person or entity providing information, the Prosecution elects to present as evidence any testimony, document, or other material so provided, the trial chamber may not order either party to produce additional evidence received from the person or entity providing the initial information. Moreover, a trial chamber is precluded by paragraph $(\mathrm{C})$ from ordering the attendance of witnesses or requiring the production of documents in order to compel the production of such additional evidence. Paragraph (D) provides that, if the Prosecutor calls a witness to introduce in evidence any information provided under Rule 70, the trial chamber may not compel that witness to answer any question relating to the information or its origin, if the witness declines to answer on grounds of confidentiality.

In practice, the application of this provision of the Rules of Procedure and Evidence was somewhat obscure, until it was clarified by the Appeals Chamber during the Milošević case.

In May 2002, the Prosecution requested the Trial Chamber to order, pursuant to Rule 70, that (i) a representative of a government furnishing confidential information be present in court during the evidence of a particular witness, (ii) the Prosecution's questioning be limited to a detailed outline agreed to by the government, and (iii) the scope of cross-examination be limited to the scope of direct examination (Hearing 30 May 2002, T.5953). In its submission before the Trial Chamber, the Prosecution asked for the witness to be heard in accordance with paragraphs (C) and (D) of Rule 70 and that two representatives of the relevant government be in court during the testimony of the witness, to deal with matters of national security that might arise.

On 25 July 2002, the Trial Chamber held that, in order for paragraphs (C) and (D) of Rule 70 to apply, the evidence of the witness had to satisfy certain criteria set down in paragraph (B) of the Rule. If the Chamber was not satisfied that these criteria were met, then Rule 70 did not therefore apply to the evidence of the witness. However, recognising the right of states to protect their national security interests, the Chamber ordered protective measures designed to match those sought by the Prosecution on behalf of the government. Specifically, the Prosecutor was ordered to tailor its examination-in-chief to exclude confidential information, cross-examination was not to be permitted beyond the subject matter of evidence-in-chief, questions as to credibility were permitted only if answers were not liable to reveal confidential information, and the two government representatives were permitted to be present (Prosecutor v. Milošević 25 July 2002; see also 23 October 2002, paras. 10-11).

Both the Prosecution and the relevant government appealed this decision. On 23 October 2002, the Appeals Chamber issued its decision and held that the determination of "whether information has been provided in accordance Rule 70(B) and so benefits from the protections afforded by that Rule" is limited to an assessment of "whether the information was in fact provided on a confidential basis" (Prosecutor v. Milošević 25 July 2002; 23 October 2002, para. 29). Once ascertained that the prospective testimony of a state official was "in fact provided on a confidential basis", the state then enjoyed the full protection of Rule 70, and the testimony may not be introduced into evidence without the state's consent. The Appeals Chamber therefore interpreted the provisions of Rule 70 to mean that a state is in full control of information it provides to a party before the Tribunal (Prosecutor v. Milošević 23 October 2003a, paras. 25-29).

In addressing the possibility that states might withhold relevant information from an accused, the Appeals Chamber observed that there were two safeguards to ensure an accused's right to a fair trial in this context. First, it held that a trial chamber does have limited authority to police the application of the rule, by determining whether the information was "in fact provided on a confidential basis"; if in doubt, the chamber should hear the information provider and the prosecution on the 
matter (Prosecutor v. Milošević 23 October 2003a, paras. 26, 29, 31). Yet this enquiry is of "a very limited nature" (Prosecutor v. Milošević 23 October 2003a, para. 29) and does not include any scrutiny as to the basis for the confidentiality, unlike compelled state documents under Rule 54 bis (F)(i), which will be discussed below. Second, the Appeals Chamber found that Rule $70(\mathrm{G})$, which empowers a chamber to "exclude evidence if its probative value is substantially outweighed by the need to ensure a fair trial", gives a chamber "a tool to protect [the fair trial] requirement if the Rule has been misused" (Prosecutor v. Milošević 23 October 2003a, para. 26).

The ruling of the Appeals Chamber therefore clarified the meaning and application of Rule 70, thereby providing more certainty to parties and states dealing with the provision of information in relation to the cases before the Tribunal.

Rule 54 bis: litigation between the Prosecution and Serbia and Montenegro over the production of

documents Throughout the trial, there was vigorously contested litigation between the Prosecution and the government of Serbia and Montenegro, formerly the FRY, over the production of documents relevant to the core proceedings. ${ }^{34}$ This litigation pursuant to Rule 54 bis took place from almost the very beginning of the trial and was still being pursued at the time of Miloševićs death and the subsequent close of the proceedings (Prosecutor v. Milošević 14 March 2006).

When the Security Council adopted Resolution 827 on 23 May 1993, it exercised its powers under Chapter VII of the UN Charter, in the form of Article 29 of the Statute, to obligate states to cooperate with the ICTY in its investigations and prosecutions. Moreover, states were enjoined to "comply without undue delay with any request for assistance or an order issued by a Trial Chamber, including, but not limited to ... the taking of testimony and the production of evidence..." (Statute of ICTY, Art. 29; see UNSC Res 827 1993; UNSC Res 955 1994). The UN Secretary-General, in his report accompanying the Statute, stated in relation to Article 29 that the establishment of the ICTY pursuant to Chapter VII "creates a binding obligation on all States to take whatever steps are required to implement" a decision of the Tribunal (UNSC 1993, para. 125). ${ }^{35}$

The ICTY's power to order the production of documents from a State was confirmed by the ICTY Appeals Chamber in Prosecutor v. Blaškić (Prosecutor v. Blaškić 29 October 1997, para. 26) and was later codified in Rule 54 bis. $^{36}$ A state's failure to comply with an order of a chamber could be reported to the ICTY President, who then must transmit this report to the UN Security Council pursuant to Rule 7 bis.
In preparation for the trial, and as early as December 2001, the Prosecution had issued requests for assistance to the FRY, in the form of requests for documents and access to identified archives (Prosecutor v. Milošević 13 December 2002, paras. 1-4). After over a year of alleged partial non-compliance with these requests by the FRY, and 10 months after the trial began, the Prosecution requested, in December 2002, the Trial Chamber to order the FRY to produce certain documents and grant the Prosecution access to 16 archives in the control of the FRY (Prosecutor v. Milošević 13 December 2002, paras. $1-5){ }^{37}$ The Prosecution emphasised that the FRY's failure to provide documents had "seriously obstructed the progress of this trial" because the use of the requested documents "may very substantially abbreviate the trial proceedings-as in the eight-month Nuremberg trial ... [which] focused on documentary evidence" (Prosecutor v. Milošević 13 December 2002, para. 4, note 2). The Prosecution also argued that the unavailability of the requested documents prejudiced the rights of victims, as well as Milošević's right to a fair trial (Prosecutor v. Milošević 13 December 2002, para. 7).

Serbia and Montenegro opposed the application in a written submission and informed the Chamber that it welcomed the opportunity to examine its cooperation with the ICTY, for example, Serbia and Montenegro's indictment and arrest of Milošević in 2001, as well as his transfer to the ICTY in June 2001 (see Prosecutor v. Milošević 7 February 2003, paras. 2-3). Moreover, Serbia and Montenegro argued that it could not be considered in non-compliance with requests for assistance pursuant to Article 29 of the Statute because the production of documentation was "a process", it had completed $58 \%$ of the Prosecution requests, and the situation had to be viewed in the context of the "new democratic authorities inherit[ing] a tremendous task of reforming an administration shaped during 12 years of Miloševićs rule" (see Prosecutor v. Milošević 7 February 2003, para. 4). After arguing that many of the requests that the Prosecution characterised as unfulfilled had in fact been fulfilled, Serbia and Montenegro rejected the proposition that anything in the Statute or Rules provided a legal basis upon which a chamber could grant a party access to state archives (see Prosecutor v. Milošević 7 February 2003, paras. 5-6, 8-17). Serbia and Montenegro furthermore argued that Article 18(2) of the Statute and Rule 39 did not authorise such an order by a chamber (see Prosecutor v. Milošević 7 February 2003, para. 14; Statute of ICTY; IT/32/Rev.44 10 December 2009). ${ }^{38}$ It was finally argued by Serbia and Montenegro that the Prosecution's application failed to meet the requirements of Rule 54 bis (A) (Prosecutor v. Milošević 7 February 2003, paras. 18-32). ${ }^{39}$ 
In a reply, the Prosecution sought to clarify that its request for access to governmental archives was not a demand for general access but rather a request "to survey archives in order to establish what documents, if any, may be pertinent to Tribunal proceedings" (see Prosecutor v. Milošević 27 February 2003, para. 3, note 8; 14 February 2003; 19 February 2003). Moreover, it argued that access to archives could be achieved not only under Rule 54 bis but also via a search warrant issued pursuant to Rules 39 and 54 and noted that such orders had been issued for official governmental buildings, including military facilities and archives in the former Yugoslavia (see Prosecutor v. Milošević 27 February 2003, paras. 8-16). ${ }^{40}$

After hearing the Prosecution and Serbia and Montenegro in March 2003, the Trial Chamber issued an oral order giving Serbia and Montenegro 2 months to respond to a priority list of documents compiled by the Prosecution (Hearing 10 March 2003, T.17526-17580; see Prosecutor v. Milošević 6 May 2003b, para. 8). In the words of the Prosecution, "Serbia and Montenegro is acting as if it is an adverse party to litigation rather than a State party assisting the International Tribunal in its search for truth and reconciliation in the former Yugoslavia" (Prosecutor v. Milošević 20 May 2003, paras. 1, 3, 21-22, notes 30-31 (citing UNSC Res 827 1993; UNSC Res 955 1994); Jorda 2002; del Ponte 2002). Another hearing was held, which resulted in a series of orders being issued by the Chamber for Serbia and Montenegro to produce thousands of documents by a particular deadline or update the Chamber of the specific reasons why it could not do so (Prosecutor v. Milošević 3 June 2003, T. 21648-21693). Among these documents were the stenographic recordings of meetings of the FRY's Supreme Defence Council (SDC), as well as documents relating to the Supreme Command and the Joint Command for Kosovo (Prosecutor v. Milošević 5 June 2003; 12 June 2003, Annex A, p. 1, Rulings 1-3). ${ }^{41}$

What followed was a prolix, labyrinthine effort by the Prosecution and the Chamber to force Serbia and Montenegro to comply with the many orders that had been issued (Prosecutor v. Milošević 15 September 2003, pp. 2-3; 17 December 2003, p. 2). After at least 13 decisions over the course of a year and with the Prosecution case almost at an end, it would have been conceivable for the Trial Chamber to bring to an end these Rule 54 bis proceedings, but instead, the Chamber showed a willingness to continue the litigation well into its second year, by issuing additional orders for the production of documents and supplemental reporting by both the Prosecution and Serbia and Montenegro. ${ }^{42}$

\section{Self-representation, Part II}

Adequate assistance At the start of the trial, the Trial Chamber turned its attention to ensuring that Milošević had adequate assistance for his defence. It considered a brief of the Amici Curiae regarding whether Milošević had access to adequate facilities to conduct his defence (Prosecutor v. Milošević 5 March 2002). The Chamber also considered a Registry Report on the matter (Prosecutor v. Milošević 18 March 2002). During a hearing on 10 April 2002, Milošević identified two lawyers as associates with whom he wished to communicate. ${ }^{43}$ Less than a week later, the Trial Chamber varied its order of 15 November 2001 and granted Milošević privileged communications with them (Prosecutor v. Milošević 16 April 2002b). In October 2003, the Trial Chamber, upon the written request of Milošević, appointed a third lawyer as a "Legal Associate". ${ }^{44}$ On 24 April 2002, the Trial Chamber found that, in accordance with Article 21 of the Statute, Milošević had adequate time and facilities for the preparation of his defence and that it was satisfied that "all possible efforts were being made to assist him" (Hearing 24 April 2002, T.3737-3740).

In October 2002, the Trial Chamber instructed the Registry to revoke the appointment of one of the Amici Curiae on grounds of apprehension of bias. That Amicus had granted interviews to several publications in which it appeared that he had "formed a view of the case unfavourable to the Accused" ${ }^{45}$ Approximately a month later, the Trial Chamber designated a new person as Amicus Curiae with respect to questions of international law. ${ }^{46}$

The Trial Chamber's first decision on assignment of counsel $^{47}$ Despite the assistance to Milošević from the three Amici Curiae and the three Legal Associates, from about 1 month into the start of the trial, Milošević began to show signs of ill health. This resulted in hearings being cancelled at the last minute and delays in the proceedings. In November 2002, the Trial Chamber expressed concern about the completion of the trial in the light of the state of Milošević's ill health and the length and complexity of the case and ordered submissions from the parties on the matter. ${ }^{48}$

A week later, the Prosecution filed a motion, proposing that the Trial Chamber appoint defence counsel for Milošević with the suggestion that the Amici Curiae be appointed to the role of defence counsel (Prosecutor v. Milošević 8 November 2002). Milošević rejected the suggestion in court a few days later (Hearing 11 November 2002, T.12837). The Amici Curiae filed their own submissions on the matter, indicating that "the interests of justice do not require the assignment of counsel, which would deprive 
Milošević of his right to conduct his own defence" (Prosecutor v. Milošević 18 November 2002, p. 6).

In December, the Trial Chamber orally rejected the Prosecution's Motion, stating that "[d]efence counsel will not be imposed upon the Accused against his wishes in the present circumstances. It is not normally appropriate in adversarial proceedings such as these. The Trial Chamber will keep the position under review" (Hearing 18 December 2002, T.14574). In April 2003, the Trial Chamber issued its written reasons for this decision (Prosecutor v. Milošević 4 April 2003, paras. 18-41), holding that the plain reading of Article 21(4)(d) of the Statute provided for a right to defend oneself in person, this interpretation being supported by the essentially adversarial nature of the ICTY proceedings (Prosecutor v. Milošević 4 April 2003, paras. 18-20). The Chamber pointed out that the imposition of a defence counsel upon an accused who does not want one was a feature of inquisitorial systems, but not of adversarial systems (Prosecutor v. Milošević 4 April 2003, para. 21). Moreover, remarked the Chamber, in Romano-Germanic legal systems, where the court was fulfilling a more investigative role in an attempt to establish the truth, it may have been appropriate to appoint defence counsel for an accused who wishes to represent himself. However, the imposition of defence counsel on an unwilling accused in an adversarial system would effectively deprive that accused of putting forward a defence, because in adversarial systems it was the responsibility of the parties to put forward the case and for the court to judge (Prosecutor v. Milošević 4 April 2003, para. 24).

The Trial Chamber did observe that "the right to defend oneself in person is not absolute ..., as there may be circumstances where it is in the interests of justice to appoint counsel" (Prosecutor v. Milošević 4 April 2003, para. 40). For example, an accused whose behaviour had resulted in his removal from the courtroom pursuant to Rule $80(\mathrm{~B}),{ }^{49}$ "has also relinquished his right to defend himself in person". The Trial Chamber held that at that point in the trial no circumstance had arisen that supported the imposition of defence counsel but stated that it would "keep the position under review". The Trial Chamber also held that, "while ensuring that the trial is fair and expeditious, a Trial Chamber must also ensure that the rights of the accused, as set out in Article 21 of the Statute, are not infringed" (Prosecutor v. Milošević 4 April 2003, paras. 40-41).

In order to lessen the physical burden on Milošević, the Chamber moved to a schedule of four consecutive rest days every other week until the end of September 2003 (Prosecutor v. Milošević 22 September 2004, para. 9). Following repeated delays in the trial and with seven hearing days having been lost in the month of September alone, on 23 September, the Prosecution filed a motion requesting a hearing to discuss the implications of Milošević's recurring ill health (Prosecutor v. Milošević 23 September 2003). The Trial Chamber ordered both the Prosecution and the Amici Curiae to make written legal submissions in relation to the proposals made by the Prosecution in its motion and thereafter to make submissions at an oral hearing on 30 September (Prosecutor v. Milošević 24 September 2003). After considering the parties' submissions, the Trial Chamber made an oral ruling to the effect that the Chamber would sit 3 days per week, giving Milošević 4 days of consecutive rest each week (Prosecutor v. Milošević 30 September 2003). Milošević was not present at the hearing due to illness.

\section{Interlude}

\section{End of the Prosecution case}

On 2 September 2003, the Trial Chamber held a status conference to discuss the anticipated conclusion of the Prosecution's case and the preparation for the presentation of the defence case (Hearing, Pre-Defence Conference, 02 September 2003, T. 25943-25945). Milošević was expected to continue to prepare his defence case during the interval between the end of the Prosecution case-in-chief and the commencement of the defence case. However, Milošević took the position that the amount of time he needed to prepare his defence case "even the barest minimum of the time ... would have to be in excess of two years" (Hearing 2 September 2003, T.25944). Milošević also reminded the Chamber that "the opposite side itself disclosed about half a million pages" of material (Hearing 2 September 2003, T.2594325945).

On 17 September 2003, the Trial Chamber ordered that the trial would be adjourned for 3 months between the close of the Prosecution's case-in-chief and the commencement of the defence case to enable Milošević to prepare his case (Prosecutor v. Milošević 17 September 2003). In January 2004, the Appeals Chamber upheld the Trial Chamber's decision (Prosecutor v. Milošević 20 January 2004).

On 25 February 2004, the Prosecution (via a written filing) rested its case-in-chief, subject to several matters pertaining to the admission of documents and its case in rebuttal (Prosecutor v. Milošević 25 February 2004a). The Trial Chamber, on the same day, issued a decision, confirming the close of the Prosecution's case-in-chief and making several rulings on outstanding motions pertaining to the admission of documentation (Prosecutor v. Milošević 25 February 2004b). ${ }^{50}$ The Trial Chamber allotted $360 \mathrm{~h}$, or 90 sitting days, to Milošević for the presentation of his case-in-chief. This was the same amount of time as the Prosecution was given, despite Miloševićs persistent claims that he only was given half 
of the time that the Prosecution was given to present his evidence (Prosecutor v. Milošević 25 February 2004c).

Amici Curiae motion for judgement of acquittal ${ }^{51}$ On 3 March 2004, the Amici Curiae filed a motion requesting that the Trial Chamber acquit Milošević on a number of charges in the indictments, pursuant to Rule 98 bis (Prosecutor v. Milošević 3 March 2004, paras. 29-32). This Rule, at the time, provided that "[a]n accused may file a motion for the entry of judgement of acquittal on one or more offences charged in the indictment within seven days after the close of the Prosecutor's case and, in any event, prior to the presentation of evidence by the defence" and that "[t]he Trial Chamber shall order the entry of judgement of acquittal on motion of an accused or proprio motu if it finds that the evidence is insufficient to sustain a conviction on that or those charges."

The Amici Curiae argued, on Milošević's behalf, that the Prosecution failed to establish the existence of an "armed conflict" in Kosovo prior to the commencement of the NATO bombing campaign on 24 March 1999, thus requiring parts of the Kosovo Indictment dependent upon this legal precondition to be dismissed (Prosecutor v. Milošević 3 March 2004, paras. 29-32; see 3 May 2004, paras. 17-75). They also argued that the Prosecution had failed to establish that Croatia was a state before some time between 15 January and 22 May 1992; thus, the conflict in Croatia was not of an international character before that time and all grave breaches counts in the Croatia Indictment that went to alleged crimes committed before these dates should be dismissed (Prosecutor v. Milošević 3 March 2004, para. 95; see 3 May 2004, paras. 122-153). Next, it was argued that the Prosecution had not adduced any or sufficient evidence that Milošević planned, instigated, ordered, committed, or otherwise aided and abetted in the planning, preparation, or execution of a genocide or that he was complicit in such acts. Along these lines, the Amici Curiae submitted that the mens rea requirement for establishing the crime of genocide was incompatible with the mens rea requirement for the third category of a joint criminal enterprise and command responsibility, as alleged in the Bosnia Indictment (Prosecutor v. Milošević 3 March 2004, paras. 161-162; see 3 May 2004, paras. 225-439). Finally, it was submitted that the Prosecution had not adduced any or sufficient evidence in relation to 185 separate allegations contained in the three indictments (Prosecutor v. Milošević 3 March 2004, sections III.E, IV.D, V.C.). ${ }^{52}$

At this point, the Presiding Judge, Richard May, who had steered the trial through the pre-trial phase and through most of the Prosecution's case-in-chief, resigned effectively on 1 June 2004, due to ill health, and Judge
Patrick Robinson took over as the Presiding Judge of the trial. Judge Iain Bonomy was appointed in order to make up the quorum of three judges (Prosecutor v. Milošević 10 June 2004). Judge May, now knighted by the Queen of England, passed away a short time later (Simons 2004).

In June, the Trial Chamber issued its decision, holding that the Prosecution had adduced sufficient evidence for a Trial Chamber to find that there existed an armed conflict in Kosovo in the FRY prior to 24 March 1999 (Prosecutor v. Milošević 16 June 2004, para. 318). The Trial Chamber also found that there was sufficient evidence that Croatia had become a state by 8 October 1991 for the purposes of Rule 98 bis and that the conflict in Croatia was thus international during the time of the grave breaches counts in the Croatia Indictment (Prosecutor v. Milošević 16 June 2004, para. 115). The motion of the Amici Curiae was thus dismissed in these respects.

With respect to the Amici Curiae submissions concerning genocide, the Trial Chamber dismissed the motion-except for the allegations of genocide in Kotor Varoš-and held that there was sufficient evidence that "there existed a joint criminal enterprise, which included members of the Bosnian Serb leadership, the aim and intention of which was to destroy a part of the Bosnian Muslims as a group, and that its participants committed genocide in Brčko, Prijedor, Sanski Most, Srebrenica, Bijeljina, Ključ and Bosanski Novi" (Prosecutor v. Milošević 16 June 2004, para 232(1)). The Trial Chamber also found that there was sufficient evidence to hold that Milošević was a participant in that joint criminal enterprise, the aim of which was also to commit crimes other than genocide and that it was reasonably foreseeable to him that, as a consequence of the commission of those crimes, genocide of a part of the Bosnian Muslims as a group would be committed by participants in the joint criminal enterprise (Prosecutor v. Milošević 16 June 2004, para. 323(2)-(3)). Finally, the Chamber found that there was sufficient evidence to hold that Milošević aided and abetted genocide or was responsible for genocide through the doctrine of superior responsibility (Prosecutor v. Milošević 16 June 2004, para. 323(4)-(5)).

Presiding Judge Robinson appended a separate opinion, discussing the legal standard to be applied to a motion for acquittal (Prosecutor v. Milošević 16 June 2004, section VI, paras. 1-18). Judge Kwon appended a dissenting opinion, with respect to the Trial Chamber's holding that the Prosecution had adduced sufficient evidence for a Trial Chamber to find that Milošević was responsible for genocide under Article 4 of the Statute under the theory of the third category of joint criminal enterprise (Prosecutor v. Milošević 16 June 2004, section VII, paras. 1-4). 
Although the decision dismissed certain allegations relating to some of the counts in the indictments, the effect of the Trial Chamber's determinations was that there was sufficient evidence to support each count challenged in the three indictments (Prosecutor v. Milošević 16 June 2004, section VII, paras. 1-4). The trial would therefore proceed to the defence phase of the proceedings (Prosecutor v. Milošević 16 June 2004, para. 316). It is interesting to note that this would turn out to be the only decision of the Trial Chamber evaluating the evidence in the trial, although the standard of proof for this motion was only whether there was sufficient evidence upon which a trial chamber could convict, rather than whether there was evidence beyond reasonable doubt regarding Milošević's responsibility.

Amending the indictments In April 2004, the Trial Chamber granted the Prosecution leave to amend the Bosnia Indictment and confirmed that the operative Bosnia Indictment was the amended Bosnia Indictment, as amended on 22 November 2002 (Prosecutor v. Milošević 21 April 2004). ${ }^{53}$

On 20 July 2004, the Trial Chamber granted the Prosecution leave further to amend the amended Croatia Indictment (Prosecutor v. Milošević 20 July 2004; see also 11 March 2004). One week later, the Trial Chamber modified this order and granted the Prosecution further leave to amend the amended Croatia Indictment. The Chamber also confirmed that the second amended Croatia Indictment was the operative indictment for the Croatia phase of the proceedings. ${ }^{54}$

In July, the Trial Chamber invited written submissions with a view of giving further consideration to ways in which the trial might be concluded in a fair and expeditious manner. Specifically, the Trial Chamber wanted to explore the possibility of severing one or more of the indictments and then finishing one of the trials first, before then proceeding to complete the other two trials (Prosecutor v. Milošević 21 July 2004). The Prosecution, the Amici Curiae, and Milošević all filed submissions on this matter. They all expressed their opposition to severing the indictments (Prosecutor v. Milošević 27 July 2004a; 27 July 2004b; Addendum 6 August 2004). It was probably the only moment in the trial when the parties agreed on something. The Trial Chamber decided not to give further consideration to the matter at that time (Prosecutor v. Milošević 25 August 2004).

\section{Self-representation, part III: taking the case away from Milošević}

On 27 June 2003, the Trial Chamber ordered that one of the Amici Curiae's appointments be concluded at the end of the Prosecution case. The Chamber also decided that the other two Amici Curiae (or simply one of them) were to be present for the first 4 weeks of the defence case (Prosecutor v. Milošević 27 June 2003, paras. 3-4(a)). After this, the Trial Chamber would determine their future role, if any, in the trial (Prosecutor v. Milošević 27 June 2003, para. 4(b)).

During the period leading up to the commencement of the defence phase of the proceedings, a "Pro Se Legal Liaison Officer" was created in order to facilitate the interaction between Milošević and his Legal Associates with various sections of the ICTY, as well as the Prosecution and Chamber. This person had responsibilities spanning from the management of documentary evidence on behalf of the Defence to coordinating the appearances of witnesses to be called by Milošević to give evidence before the Chamber (see, e.g. Prosecutor v. Milošević 8 July 2005, p. 2)..$^{55}$

Milošević continued to experience ill health during February 2004 at the end of the Prosecution case and throughout the time allocated for the preparation of his defence. By that stage, the trial had been interrupted during the course of the Prosecution's case over a dozen times on account of the ill health of Milošević, causing the loss of some 66 trial days. The defence case, scheduled to start on 8 June, was postponed on five occasions, again on account of the ill health of Milošević.

The Trial Chamber heard oral submissions from the parties on 5 July 2004 on this matter. At that hearing, there was discussion of recent health reports. The Amici Curiae raised two issues: Milošević's fitness to present his defence at this time and his fitness to stand trial at all (Hearing 5 July 2004, T.32143). While holding that there was no evidence before the Trial Chamber that Milošević was not fit to stand trial, the Trial Chamber considered that there was evidence indicating that the health of Milošević was such that he might not be fit to continue to represent himself and that the continuation of his self-representation could adversely affect the fair and expeditious conduct of the trial. Such was the concern of the Trial Chamber that it decided to "carry out a radical review of the trial process and the continuation of the trial in the light of the health problems of the Accused, which are clearly chronic and recurrent based on the most recent report from the doctor" (Hearing 5 July 2004, T.32153-32154).

The Trial Chamber subsequently directed the Registrar to identify a cardiologist with no prior involvement in the treatment of Milošević. He would be instructed to examine Milošević and consider all relevant information pertaining to his fitness to continue to represent himself and the likely impact on the trial schedule, should he continue to do so (Prosecutor v. Milošević 6 July 2004). ${ }^{56}$ In mid-July, the Trial Chamber issued an identical request to the doctor who had been treating Milošević for cardiological problems for some time (Prosecutor v. Milošević 15 July 2004). 
Later that summer, the Trial Chamber sought submissions about the role that counsel could take in ensuring the fair presentation of the defence case, in particular in the absence of Miloševićs cooperation with counsel or his refusal to give them instructions (Prosecutor v. Milošević 6 August 2004). In August, written submissions on the issue of assigning counsel to Milošević were submitted by the Prosecution and the Amici Curiae (Prosecutor v. Milošević 26 July 2004b; 19 August 2004; 13 August 2004; Addendum 6 August 2004). Milošević made no written submissions. In September, the Prosecution, the Amici Curiae, and Milošević each addressed the Trial Chamber in relation to the future conduct of the case. The issue to be decided was whether Milošević should be assigned counsel-against his wishes-in order to ensure his right to a fair trial.

Having heard all the submissions and having considered all the related filings submitted during the summer of 2004 (Prosecutor v. Milošević 26 July 2004b; 27 July 2004a; 19 August 2004; 27 July 2004b; 13 August 2004; Addendum 6 August 2004), the Trial Chamber gave the following oral ruling on 2 September:

In its reasons for its decision on the Prosecution motion concerning assignment of Defence counsel of 4 April 2003, the Trial Chamber, while holding that the accused had a right to defend himself, also held in paragraph 40 that the right to defend oneself in person is not absolute and that it would keep the position under review .... The health of the accused has been a major problem in the progress of the trial. In the Prosecution's case, the trial was interrupted over a dozen times on account of the ill health of the accused, thereby losing some 66 trial days.

The Defence case that was scheduled to start on 8 June was postponed on five occasions, again on account of the ill health of the accused. The Trial Chamber requested Dr. van Dijkman, who has been treating the accused for cardiological problems for some time, and Professor Tavernier from Belgium, who was identified by the registrar as a cardiologist with no prior involvement in the treatment of the accused, to examine the accused and consider all relevant information pertaining to his health in the context that he represents himself, and report to the Trial Chamber on the fitness of the accused to continue to represent himself and the likely impact on the trial schedule should he continue to do so. Both doctors reported that the accused suffers from severe essential hypertension and that his condition was such that a hypertensive emergency, a potentially lifethreatening condition, could develop. They also found that one explanation for his medical condition was his failure to adhere to the proposed therapeutic plan. Blood tests carried out on the accused confirmed this conclusion. It is plain from the medical reports that the accused is not fit enough to defend himself and that, should he continue to represent himself, there will be further delays in the progress of the trial. The issue before the Chamber is whether the right of an accused set out in Article 21 of the Statute to defend himself in person is subject to qualification, and if it is, whether in the circumstances of this case that right should be qualified by assigning counsel to represent the accused.

The Chamber is satisfied, on the basis of the Tribunal's Statute and the jurisprudence, as well as the law of many domestic jurisdictions, that the right of an accused person to represent himself is not unfettered, and in the circumstances of this case, it is both competent to assign counsel to the accused and in the interests of justice to do so. We shall, therefore, do so.

The fundamental duty of the Trial Chamber is to ensure that the trial is fair and expeditious. The concern of the Chamber is that, based on the medical reports, there is a real danger that this trial might either last for an unreasonably long time or, worse yet, might not be concluded, should the accused continue to represent himself without the assistance of counsel. On the other hand, the Chamber is satisfied that, if counsel is assigned to the accused, measures can be devised to ensure that the trial continues in a manner that is both fair and expeditious.

Having decided to assign counsel to the accused, it will be the duty of the Chamber to ensure that the role of assigned counsel is so fashioned that the trial process, while being expeditious, will protect the fundamental right of the accused to a fair trial (Hearing 02 September 2004, T.32357-32359; see Prosecutor v. Milošević 22 September 2004).

Following this oral ruling and in furtherance of its duty to ensure that the role of Assigned Counsel was so fashioned that the trial process would protect the fundamental right of Milošević to a fair trial, the Chamber issued an order in which it set out, with specificity, the functions that the Assigned Counsel would undertake and the role that Milošević would play in his defence. Assigned Counsel had the duty to determine how to present the defence case for Milošević, including choosing, preparing, and examining witnesses; making submissions on fact and law; seeking orders from the Trial Chamber that they considered necessary to enable them to present the defence case properly; discussing with Milošević the conduct of the case and endeavouring to 
obtain his instructions; taking into account of Miloševićs views, while retaining the right to determine what course to follow; and acting in Miloševićs best interests. The Trial Chamber authorised Milošević, with the leave of the Trial Chamber, to continue to participate actively in the conduct of his case, including, where appropriate, examining witnesses after Assigned Counsel had done so. The Chamber, in its order, reminded Milošević that he still retained the right, at any time, to make a reasonable request to the Trial Chamber to consider allowing him to appoint counsel (Prosecutor v. Milošević 3 September 2004, pp. 2-3).

The Trial Chamber stated that it was satisfied that Assigned Counsel would make determined efforts to discuss the presentation of Miloševićs defence with him. Should Milošević fail to cooperate with counsel, the trial would nonetheless proceed. The Trial Chamber further held that, if such failure on the part of Milošević resulted in material relevant to Milošević's case not being presented, then Milošević had to bear responsibility and could not plead injustice (Prosecutor v. Milošević 22 September 2004, para. 70).

\section{The defence case}

\section{Parameters of the defence case}

On 25 February 2004, the Trial Chamber ordered that Milošević would have the same time as the Prosecution to present his case-in-chief. The Prosecution had spent approximately $360 \mathrm{~h}$ presenting its case-in-chief or approximately 90 sitting days (Prosecutor v. Milošević 25 February 2004, para. 1). The Trial Chamber then added two thirds of that time for cross-examination of witnesses called by the defence and administrative matters, which amounted to approximately $240 \mathrm{~h}$ or 60 sitting days (Prosecutor v. Milošević 25 February 2004, para. 2). Milošević would therefore have 150 sitting days in which to present his case, a period that was subject to adjustment depending upon the time taken in crossexamination and administrative matters (Prosecutor v. Milošević 25 February 2004, para. 4).

At the pre-defence conference of 17 June 2004, a number of orders were made concerning the management of the defence case. Milošević was limited to 150 sitting days to present his case, regardless of the number of witnesses he had on his list. The Trial Chamber noted that it did not seek to limit the number of witnesses Milošević could call but rather encouraged him to make use of the procedures available under Rules 92 bis and 89(F). Milošević was ordered to produce a weekly list of witnesses. He was ordered to disclose to the Prosecution copies of all exhibits on his Rule 65 ter list within 7 days. Milošević was required to make written filings when ordered by the Trial Chamber to do so. He was allowed to make an opening statement of not more than $4 \mathrm{~h}$, to which the Prosecution was not allowed to respond. Milošević was ordered to make a separate written application for each witness whom he would seek to subpoena. Finally, Milošević was ordered to make a written application for the production of documents or other information from states and to comply with all procedural requirements; oral applications would not be considered (Prosecutor v. Milošević 17 June 2004, paras. 1, 3, 9-10, 12, 18-19). In complying with all of these tasks, Milošević had the assistance of Assigned Counsel, his Legal Associates, and the Pro Se Legal Liaison Officer.

During the pre-defence conference, Milošević informed the Chamber that he anticipated a witness list that would include 1631 persons (Prosecutor v. Milošević 17 June 2004, T.32125) and that between 1300 and 1400 witnesses had agreed for their names to be disclosed to the Trial Chamber (Prosecutor v. Milošević 17 June 2004, T.32084). Milošević was scheduled to commence the presentation of his defence on 5 July 2004 but was unable to do so due to medical concerns (Hearing 5 July 2004, T.32135). His opening statement was not presented until 31 August and 1 September 2004 (Hearing 31 August and 1 September 2004, T.32157-32298). After the opening statement, the Trial Chamber adjourned for 4 weeks to enable further preparation for the defence case. The trial resumed on 12 October 2004.

In a May 2005 order, the Trial Chamber made some modifications to the use of time in the defence case (Prosecutor v. Milošević 19 May 2005). The time allocated to the Prosecution for cross-examination was revised to $216 \mathrm{~h}$ or 54 sitting days, being $60 \%$ of the time allotted to Milošević. It was furthermore ordered that a separate record of time spent on administrative matters be kept but that it should not be counted against the time allotted to Milošević (Prosecutor v. Milošević 19 May 2005, para. 3). The Trial Chamber clarified that "administrative matters are those which do not fall into the category of procedural issues" arising from examination of witnesses, "including discussion of the admissibility of exhibits and other matters as determined by the Trial Chamber" (Prosecutor v. Milošević 19 May 2005, para. 3).

\section{Self-representation, part IV: giving the case back to Milošević}

Assigned Counsel encountered problems almost immediately and complained about the lack of cooperation from witnesses and from Milošević himself. For example, Assigned Counsel only managed to call 5 out of a list of 140 witnesses, many of whom refused to give evidence in protest against the Trial Chamber's decision to appoint counsel to Milošević against his wishes. In October 2004, Assigned Counsel wrote a letter to the Registrar seeking to be withdrawn from their position as Counsel 
(Prosecutor v. Milošević 27 October 2004a). The Registrar deemed that it was more appropriate for the Trial Chamber to decide the matter (Prosecutor v. Milošević 27 October 2004b). The Trial Chamber rendered its decision in December, holding that Assigned Counsel were neither entitled to withdraw nor to terminate their assignment unilaterally (Prosecutor v. Milošević 7 December 2004, para. 26). In accordance with this decision, the Registrar denied the Assigned Counsel's request (Prosecutor v. Milošević 14 December 2004).

The Assigned Counsel then turned to the President of the ICTY and asked him to review the Registrar's decision to refuse their application to withdraw. In a decision of February 2005, the President held that the refusal of an accused to cooperate with his lawyers did not mean that the Registrar was required to withdraw the assignment of counsel under Article 19(A) of the ICTY Code of Conduct (Prosecutor v. Milošević 7 February 2005a, para. 10 citing paras. 53, 54 of Prosecutor v. Blagojević). In fact, any other holding in the present case would in effect give Milošević the power to render the decision that counsel should be assigned meaningless by simply refusing to cooperate with the Assigned Counsel (Prosecutor v. Milošević 7 February 2005a, para. 10).

In November 2004, the Appeals Chamber affirmed the Trial Chamber's decision to impose Counsel upon Milošević, but reversed the Trial Chamber's order on the modalities by which that representation would function. The Appeals Chamber held that the Trial Chamber should craft a working regime that minimised the practical impact of the formal assignment of counsel. Such a regime had to be rooted in the default presumption that Milošević should take the lead in presenting his case whenever he was able to do so, such as choosing which witnesses to present, questioning the witness before Assigned Counsel is given the opportunity to do so, arguing any proper motion he wished, giving a closing statement, and making the basic strategic decisions about the presentation of his case. The Appeals Chamber stressed that Assigned Counsel should only step in where Milošević's health prevented him from presenting his own defence (Prosecutor v. Milošević 22 September 2004, paras. 19-20).

The Assigned Counsel were thus effectively returned, by the Appeals Chamber, to the previous role they had occupied while they were Amici Curiae, which was, in essence, stand-by counsel. Milošević was back in control of his case.

\section{Evidentiary matters}

Admission of documents: setting the ground rules A February 2005 order set forth the Trial Chamber's general approach to the admission of defence evidence during Miloševićs case-in-chief (Prosecutor v. Milošević 7 February 2005b). In this order, the Trial Chamber sought to lay out general ground rules for the copious amounts of evidence that Milošević said he would tender during his case, much of which had not yet been translated into a working language of the Tribunal (Prosecutor v. Milošević 7 February 2005b).

During the defence case, the Prosecution attempted to adduce evidence to prove its case against Milošević during its cross-examination of Milošević's own witnesses. The matter was litigated (Prosecutor v. Milošević 15 March 2005) and resulted in a ruling by the Trial Chamber that, although the Prosecution could put material to a witness during cross-examination in accordance with Rule 90(H) (Prosecutor v. Milošević 17 May 2005), ${ }^{57}$ it was not allowed to have the material admitted when a defence witness could offer no meaningful evidence in relation to the tendered material (Prosecutor v. Milošević 17 May 2005, para. 9). This ruling precluded the Prosecution from admitting a large body of material through Miloševićs witnesses during the defence case.

\section{Application to subpoena Tony Blair and Gerhard} Schröder In August 2005, Assigned Counsel filed applications requesting that a binding order be issued to the government of the United Kingdom and the Federal Republic of Germany. Assigned Counsel wanted the UK and Germany to arrange for pre-testimony interviews and the appearance in court of UK Prime Minister Tony Blair and former German Chancellor Gerhard Schröder.

In its decision, the Trial Chamber first clarified that the subpoena of a state official was appropriately brought under Rule 54, rather than the provisions of Rule 54 bis, which were devoted to the compulsion of documentary evidence from a state. The Trial Chamber then articulated the legal standard for the issuance of a subpoena ad testificandum as such: the moving party must show that a subpoena is "necessary ... for the preparation or conduct of the trial", and this includes a twopronged test: a reasonable basis must be shown that the prospective witness is likely to give information that will materially assist the applicant with respect to specific issues in the trial ("legitimate forensic purpose" requirement), and this information cannot be obtainable through other means ("last resort" requirement). The Trial Chamber further clarified that "an applicant for a subpoena must be specific about the information sought from the prospective witness and must demonstrate a nexus between this information and the case against the accused". The Trial Chamber, after having examined in detail the issues in relation to which the Assigned Counsel wished to subpoena Blair and Schröder, decided that there was no legitimate forensic purpose for the their testimony nor was it necessary in order to ensure 
that the trial was fair and informed (Prosecutor v. Milošević 9 December 2005).

Having found that the application failed on its merits, the Trial Chamber did not need to decide whether the status of the prospective witnesses as senior state officials gave them immunity from being compelled to attend an interview or testify before the Tribunal (Prosecutor v. Milošević 9 December 2005, para. 67).

Resurfacing of the Rule 54 bis litigation Many of the documents adduced by the Defence during the direct examination of witnesses led the Prosecution to request the Chamber to take further action in relation to prior Rule 54 bis applications. In August 2005, almost a year after the start of the defence case, the Prosecution argued in a renewed Rule 54 bis motion that the testimony of Božidar Delić revealed that the Defence had been provided with extensive access to VJ documents, documents that had been the subject of prior litigation between the Prosecution and Serbia and Montenegro (see Prosecutor v. Milošević 24 August 2005, para. 2).

The Chamber ordered Serbia and Montenegro to file publicly an explanation for "why it did not previously produce, and to this date still has not produced, the two 'Joint Command' documents tendered by witness Božidar Delić during his testimony, despite the fact that [a previous decision had] called for the production of such documents" (Prosecutor v. Milošević 31 October 2005, para. 4(a)). The Chamber noted that Serbia and Montenegro was "still bound by [a previous decision] that Serbia and Montenegro 'continue its efforts to locate the requested documentation' and produce such documentation to the Prosecution, and that a state must always perform its legal obligations in good faith" (Prosecutor v. Milošević 31 October 2005). ${ }^{58}$

\section{Milošević's motion for an extension of time}

In December 2005, the Trial Chamber denied Milošević's motion for an extension of time in which to present his defence case (Prosecutor v. Milošević 13 December 2005a). In so doing, the Chamber held that, as of 30 November 2005, Milošević had used $75.35 \%$ of the time allotted to him. Despite repeated warnings by the Chamber to use his time to address evidence in relation to all three indictments against him, Milošević had led almost entirely Kosovo-related evidence (Prosecutor v. Milošević 12 December 2005, para. 16). Moreover, despite having been urged by the Chamber on several occasions to make use of the procedural mechanisms of Rules $89(\mathrm{~F})$ and 92 bis for the admission of written evidence in lieu of oral testimony, he insisted on leading all evidence viva voce in court (Prosecutor v. Milošević 12 December 2005, para. 16).

\section{Prosecution's attempt to re-open its case-in-chief}

Earlier on, in July 2005, about a year and a half after closing its case-in-chief against Milošević, the Prosecution had sought the re-opening of its case in order to present six new witnesses and 50 new documents (Prosecutor v. Milošević 18 July 2005). This evidence substantively fell into five categories related, according to the Prosecution, to key issues in its case as follows: a plan to ethnically cleanse Bosnia of its Muslim population dating from at least 1992; the involvement of the VJ in the war in Bosnia between 1992 and 1995; the involvement of Serbia's Ministry of Interior in the Bosnian war between 1992 and 1995, including in the Srebrenica massacre; VJ personnel files of high-ranking military officials involved in the wars in Bosnia; and VJ involvement in the Račak massacre in Kosovo in 1999 (Prosecutor v. Milošević 13 December 2005b, para. 16).

After articulating the legal standard for re-opening, the Trial Chamber conducted a detailed analysis of each of the items of evidence that the Prosecution desired to tender as evidence (Prosecutor v. Milošević 13 December 2005b, paras. 7-15). This analysis included an examination of whether the items had been newly obtained (Prosecutor v. Milošević 13 December 2005b, paras. 20-23) and whether the Prosecution has exercised reasonable diligence in relation to the evidentiary items (Prosecutor v. Milošević 13 December 2005b, paras. 24-32). After having found that some of the items met this test, the Chamber then went on to assess whether it should exercise its discretion to allow the re-opening of the Prosecution's case for these items, which entailed weighing the probative value of the evidence against the need to ensure a fair trial.

The Chamber considered that the exceptional measure of re-opening the Prosecution's case-in-chief-which was certain to cause delay and which was at a late stage of a trial (begun three and a half years before the motion was made) - was warranted only where the probative value of the proposed evidence was particularly high. Based upon the extensive evidence already adduced during the Prosecution's case-in-chief, the Trial Chamber was of the view that none of the items for which reasonable diligence was established had sufficient probative value to warrant admission as the basis of a re-opened case-in-chief. Although most of the items had some probative value in relation to the underlying offences charged in the indictments, none was of significance for the ultimate legal question of whether Milošević was responsible for the alleged crimes. The Prosecution's request to re-open its case was therefore denied (Prosecutor v. Milošević 13 December 2005b, paras. 37-38).

Judge Kwon issued a separate opinion agreeing with the majority in the outcome of the decision but disagreeing with the majority in the approach to materials in the 
possession of the Prosecution before the close of its case-in-chief and with its reluctance to adopt a "miscarriage of justice standard" to such material. Judge Kwon also disagreed with the majority's application of the reasonable diligence standard to certain material (Prosecutor v. Milošević 13 December 2005b: Separate Opinion of Judge O-Gon Kwon, para. 1).

\section{Epilogue: from The Hague to the former Yugoslavia \\ Health \\ Attempt to be provisionally released}

In mid-November 2005, pursuant to an oral order from the Trial Chamber (Hearing 15 November 2005, T.46481-46484), ${ }^{59}$ the Registry received and filed reports of three physicians who had conducted medical examinations of Milošević in early November. ${ }^{60}$ Following an oral request by Milošević for provisional release in mid-December (Hearing 12 December 2005, T.472584725), Assigned Counsel requested that the Trial Chamber grant Milošević's request for the purpose of medical treatment in Moscow (Prosecutor v. Milošević 20 December 2005). ${ }^{61}$ In January 2006, the Trial Chamber instructed the Defence to submit any additional material, including the guarantees from the Russian Federation (Prosecutor v. Milošević 11 January 2006, p. 3). One week later, this was done, along with a personal undertaking from Milošević (Prosecutor v. Milošević 22 December 2005). ${ }^{62}$

On 23 February 2006, the Trial Chamber denied the request on the basis that Assigned Counsel had made no real attempt to demonstrate that Miloševićs medical needs could not be met in The Netherlands (Prosecutor v. Milošević 23 February 2006, para. 17). Moreover, the Trial Chamber held as follows:

In any event, the Chamber notes that the Accused is currently in the latter stages of a very lengthy trial, in which he is charged with many serious crimes, and at the end of which, if convicted, he may face the possibility of life imprisonment. In these circumstances, and notwithstanding the guarantees of the Russian Federation and the personal undertaking of the Accused, the Trial Chamber is not satisfied that the first prong of the test has been met-that is, that it is more likely than not that the Accused, if released, would return for the continuation of his trial

(Prosecutor v. Milošević 23 February 2006, para. 18).

\section{Death}

On 11 March 2006, Milošević was found dead in his cell. As a result, on 14 March 2006, the Trial Chamber officially terminated the proceedings (Prosecutor v. Milošević 14. March 2006).
By order of the ICTY President dated 11 March 2006 and pursuant to Rule 33 of the Rules of Detention, Judge Kevin Parker was assigned to conduct a full inquiry into the circumstances surrounding the death of Milošević and to report his findings to the President. This was done on 30 May 2006 (Parker 2006). The report referred to an autopsy conducted by the Dutch Forensic Institute, confirming that Milošević died of natural causes from a heart attack. The autopsy results also indicated that no poisons had been found in Miloševićs body (Parker 2006, p. 40, paras. 2, 31, 36, 38-39). According to the report,

[n] othing has been found to support allegations reported in some sections of the media that $\mathrm{Mr}$. Milošević had been murdered, in particular by poisoning. The results of the independent investigation by the Dutch authorities demonstrate that such allegations are entirely false. (Parker 2006, p. 40 , para. 3 ).

This latter finding was most likely related to some media reports speculating that Milošević had been murdered, in particular by poisoning.

\section{Rule 54 bis: the end of the litigation with Serbia and Montenegro}

In what was to be the last days of the trial, the Prosecution was still pursuing documents from Serbia and Montenegro and requesting the Trial Chamber to issue new orders for the production of these documents. In February 2006, it was announced in open session that there was to be a closed session hearing held on motions made by the Prosecution under Rule 54 bis and on Serbia and Montenegro's request for protective measures (Hearing 2 February 2006, T.47780-47782). In March, the Trial Chamber issued a decision granting many of the Prosecution's requests for relief and ordered Serbia and Montenegro to produce various documents-or, in the event of non-production, to provide explanations of the steps taken to locate the documents (Prosecutor v. Milošević 12 April 2006, para. 14).

On 15 March 2006, Serbia and Montenegro moved the Trial Chamber to vacate or suspend indefinitely its decision of 9 March, arguing that termination of the proceedings deprived the order of its purpose and rendered it without any legal effect (Prosecutor v. Milošević 12 April 2006, paras. 9-10). The Trial Chamber decided that its decision was no longer operative from the date of the termination of the proceedings and noted that the decision's "status at that time was that it had not yet been complied with .... In light of this, it is not necessary for the Chamber to 'vacate' or 'suspend' the effect of the Decision” (Prosecutor v. Milošević 12 April 2006, para. 
19). The Trial Chamber dismissed Serbia and Montenegro's motion to vacate as unnecessary, thus bringing to an end the litigation over the production of documents between the Prosecution and Serbia and Montenegro, at least in the Milošević trial.

However, many of the documents that were produced pursuant to orders issued by the Trial Chamber in the Milošević trial ended up being used in other trials, such as the Perišić and Milutinović et al. trials.

\section{Conclusion}

At the time of the termination of the case, Milošević had about $20 \%$ of the time remaining that he had been given to present his case (Prosecutor v. Milošević 12 December 2005, para. 16). As mentioned before, on 12 December 2005, the Trial Chamber had denied a motion by Milošević for more time, due to the fact that he had squandered the time he had been given, despite multiple warnings and guidance from the Chamber (Prosecutor v. Milošević 12 December 2005, paras. 16-26). The defence case was therefore almost at an end.

One week after the death of Milošević, tens of thousands attended a farewell ceremony in Belgrade. He was subsequently buried in his home town Pozarevac, in the absence of his wife and other immediate family members, who were not living in the former Yugoslavia. The national authorities neither allowed him a state funeral nor did they attend the ceremonies (BBC 2006). Thus came to an end Miloševićs judicial journey. Having left Belgrade 5 years earlier for The Hague, he would now rest back in the former Yugoslavia-neither convicted nor acquitted. Despite this eternal judicial limbo, it is important to evaluate the effects of the trial upon international criminal justice.

The Milošević proceedings illustrated the challenge of conducting complex criminal proceedings involving allegations of mass crimes, while still endeavouring to ensure a fair and expeditious trial. The size and scope of the indictments and the question of self-representation constituted a most fragile combination. The efforts of the Chamber to temporally delimit the length of the Prosecution case-in-chief-and eventually the defence case-can be viewed as "classic" examples of the managerial judging system, as opposed to the adversarial or inquisitorial systems of law (Langer 2005). But when Milošević's poor health was added to the mix, the results were the inability to complete the trial (see Additional file 2). The Trial Chamber's two attempts to sever the Kosovo case from Croatia and Bosnia cases were probably the best chances, at later stages of the proceedings, to bring at least one of the cases to a conclusion, but these overtures were rejected by the Prosecution, Milošević, and the Amici Curiae (Prosecutor v. Milošević 12 December 2005, para. 7).
Despite Milošević's protestations that he had been provided with inadequate resources in order to lodge his defence, Milošević benefited from a wide range of assistance outside the courtroom. The extent to which Milošević's Legal Associates were involved in the preparation of his defence was often demonstrated by the detailed knowledge that Milošević had of the witnesses, which was displayed during his cross-examination of them. Moreover, throughout the Prosecution case, Milošević had three Amicus Curiae to assist him with legal submissions and the cross-examination of witnesses. ${ }^{63}$ The Chamber had also assigned, during Milošević's defence case, two lawyers and a defence team to assist him with the presentation of his case, not to mention the creation of an entirely new office-a Pro Se Legal Liaison Office-which was staffed by several persons to assist Milošević in preparing and presenting his defence (Prosecutor v. Milošević 12 December 2005, para. 21). A perusal of the public orders and decisions issued by the Chamber reveals that Milošević was in fact receiving aid from a number of different individuals throughout the course of the trial. When one is therefore talking about Milošević "representing himself", it is important to keep in mind the reality of the situation and the full picture of the assistance that Milošević was receiving from many different quarters.

In fact, the elaborate arrangements that were put into place for Milošević's purported "self-representation" call into question the meaning of the very term "self-representation". The limits of self-representation have also been tested in subsequent cases before the Tribunal, such as the Krajišnik and Karadžić cases (see, e.g. Prosecutor v. Krajišnik 11 September 2007; Prosecutor v. Karadžić 7 May 2009). It may be that an accused opting for "self-representation" is more to be understood as retaining complete control over the day-to-day management of his case, rather than as actually doing the legal work that a lawyer would normally conduct. Being represented by a lawyer can, in this sense, be viewed as a delegation of control of the case from the accused to the lawyer, whereas self-representation keeps the accused in the driver's seat. It also, however, places control in the hands of a person, the accused, who has no professional duties to the court or to the administration of justice. It therefore can set the stage for an abuse of the judicial process.

Although the Milošević trial will forever remain unfinished, the issue of the utilisation of the records of the proceedings should not be underestimated. According to Human Rights Watch:

Future generations will use the evidence to understand the region's history and how the conflicts came to pass. Because no truth commission has been 
established to look into the events in the region, the Milosevic trial may be one of the only venues in which a great deal of evidence was consolidated about the conflicts (Human Rights Watch 2006, p. 14).

Over an extended period of time, the Trial Chamber displayed a willingness to engage with the Prosecution and Serbia and Montenegro in a series of procedurally and substantively complex circumstances surrounding a multitude of documents. And yet, the Chamber did not stray from its impartial role as an arbiter interposed between two opponents, balancing the need of the Prosecution for documents to prove its case and Serbia and Montenegro's concerns. The Trial Chamber's approach resulted in documents being produced to the Prosecution by Serbia and Montenegro that otherwise would not have been produced. Materials produced in the Milošević case have been used in cases before other international courts, such as the genocide case brought by Bosnia and Herzegovina against Serbia and Montenegro at the International Court of Justice (Bosnia and Herzegovina v. Serbia and Montenegro 2007). Finally, materials obtained in the Milošević trial will be of interest to historians and political scientists seeking to gain an understanding of the events that took place during the dissolution of the SFRY.

Although Milošević's trial never came to a conclusion, another ICTY Trial Chamber in a subsequent case made findings of fact beyond reasonable doubt regarding Milošević's involvement in the Kosovo conflict in 1999. The case of Prosecutor v. Milutinović et al.-otherwise known as the "Milošević Generals Trial"-was the original Kosovo case against Milošević and his codefendants Milan Milutinović, Nikola Šainović, and Dragoljub Ojdanić, who were all indicted together for crimes committed in Kosovo during the NATO bombing campaign in the summer of 1999. After Milošević was severed from the multi-accused trial in order to be tried alone (Prosecutor v. Milošević, Milutinović, Šainović, Ojdanić, and Stojiljković 5 September 2002), his codefendants were tried later, from 2006 to 2009 in their own trial, along with three other defendants who were joined to the case. As a result, the Milutinović et al. case was essentially the Kosovo case without Milošević. As such, Milošević featured heavily in the trial and throughout the extensive four-volume Judgement.

In the final findings of the Trial Chamber, it was determined-beyond reasonable doubt-that Milošević shared, with the other members of a joint criminal enterprise, the intent to forcibly displace part of the Kosovo Albanian population, both within and outside Kosovo, and thereby change the ethnic balance in the province to ensure continued control by the FRY and Serbian authorities over it (Prosecutor v. Milutinović et al. 26 February 2009, vol. 3, paras. 466, 781, 1130). The Trial Chamber also found that there was a clandestine operation to exhume over 700 bodies originally buried in Kosovo and transfer them to Serbia during the NATO bombing and that Milošević was involved in organising this large-scale operation. The purpose of this operation was to conceal hundreds of bodies from the international representatives and NATO ground forces, whose presence on the ground in Kosovo was anticipated following the NATO bombing. The Trial Chamber concluded that Milošević knew that the great majority of the corpses moved were victims of crimes and were civilians, including women and children (Prosecutor v. Milutinović et al. 26 February 2009, vol. 3, para. 87).

But ultimately the most important outcome of the Milošević trial is that it demonstrated, for the first time in the post-World War II international criminal justice setting, the implementation of the concept of accountability of heads of state for the commission of the most serious crimes of concern to humanity. While in the 1990s this was still a questionable endeavour, it has now become an accepted fact. Today, "being sent to The Hague" has become an expression used to refer to toplevel military and political leaders being held accountable for their alleged misdeeds. From the transfer of Milošević to The Hague to the last day of his trial, the public-both in the Balkans and the rest of the world-could witness day after day the appearance, the actions, and the reactions of a head of state in an international criminal court, examining and cross-examining witnesses and interacting with the Prosecution and the Judges. And this was in the cold light of the courtroom, rather than through the filters of the media and politics. Practical and legal lessons must be learned from the Milošević proceedings. ${ }^{64}$ But it was the piercing of the corporate veil surrounding heads of state that constitutes the ultimate achievement of the Milošević trial. The daily grind of the courtroom offered the public the unprecedented opportunity of scrutinising a head of state's conduct in relation to a state's political and military apparatus. By bringing someone previously "untouchable" to the courtroom, the ICTY challenged-and ultimately dispelled-the myth of impunity. It is this iconoclastic deed that changed international criminal justice irreversibly. And this was no minor feat.

\section{Endnotes}

${ }^{1}$ The first head of state to be convicted by a supranational criminal court, more specifically, by the International Military Tribunal, was Admiral Karl Doenitz who, following Hitler's death, became on 1 May 1945 the head of state of the Third Reich. See Lillian Goldman Law Library 2008. 
${ }^{2}$ See also Judah 2002, p. 65: "On 16 July 1990 the Serbian League of Communists officially transformed itself into the Socialist Party of Serbia (SPS) and elected Milošević as its head."

${ }^{3}$ On 19 April 1993, the Secretary-General addressed a letter to the President of the UNSC informing him that the report would be made available to the UN Security Council no later than 6 May 1993. The ICTY was considered an ad hoc tribunal due to the manner in which it was created and its specific temporal and territorial jurisdiction. It is commonly considered the first truly international criminal court to try individuals for the alleged commission of international crimes, as opposed to the post-World War II tribunals, whose membership was restricted to the allied powers that had emerged victorious from that conflict. The personal jurisdiction of the ICTY is limited to individuals, as opposed to states. See Statute of ICTY, Arts. 1, 6. The temporal jurisdiction is over crimes alleged to have been committed from 1 January 1991 (see Statute of ICTY, Arts. $1,8)$, and the geographic jurisdiction is over crimes alleged to have been committed on the territory of the former Yugoslavia (Statute of ICTY, Arts. 1, 8). Finally, the ICTY has both concurrent and primary jurisdiction over national courts (Statute of ICTY, Art. 9), unlike the later-established International Criminal Court, which operates jurisdictionally upon the principle of complementarity.

${ }^{4}$ The last page of this document is signed by Louise Arbour and dated 22 May 1999. The filing date indicated upon the cover page is the next day, 23 May 1999.

${ }^{5}$ On 29 June 2001, the President of the Tribunal assigned the case to Trial Chamber III (Prosecutor v. Milošević, Milutinović, Šainović, Ojdanić, and Stojiliković 29 June 2001a), which confirmed the amended Indictment against Milošević. Prosecutor v. Milošević, Milutinović, Šainović, Ojdanić, and Stojiljković 29 June $2001 \mathrm{~b}$ (granting leave to amend the original indictment by substituting for it the proposed amended indictment, which was annex to the Motion of 29 June 2001, and confirming the amended indictment). See also Corrigendum, 2 July 2001 (correcting footnote two of the above decision to read "Motion to Substitute Proposed Amended Indictment, 29 June 2001").

${ }^{6}$ According to the order for detention on remand, issued on 3 July 2001, Milošević was arrested on 30 March 2001 and was transferred to the UNDU in The Hague on 29 June 2001. (Prosecutor v. Milošević 3 July 2001a). The ICTY website states that Milošević was transferred to the custody of the Tribunal on 29 June 2001 (see ICTY Case Information Sheet); this may be due to the fact that Milošević ultimately arrived at the UNDU close to midnight, at 11:00 p.m. See Human Rights Watch 2006, p. 10.
${ }^{7}$ Noting that the pro se liaison officer had filed submission on behalf of Milošević requesting admission of documents tendered as evidence through witness Obrad Stevanović and setting forth arguments in support of their admission into evidence.

${ }^{8}$ This rule provides that the Trial Chamber shall, if "the Accused fails to enter a plea at the initial or any further appearance, enter a plea of not guilty on the Accused's behalf." (IT/32/REV.21, Rule 62(iv)).

${ }^{9}$ Rule 74 (Amicus Curiae) reads: "A Chamber may, if it considers it desirable for the proper determination of the case, invite or grant leave to a State, organization or person to appear before it and make submissions on any issue specified by the Chamber."

${ }^{10}$ These were Steven Kay from the UK, G. Branislav Tapušković from the FRY, and Mischa Wladimiroff from The Netherlands. They all had previously served as counsel to the defence before the ICTY (in the Tadić and Čelebići cases).

${ }^{11}$ For example, the Trial Chamber also invited the Amici Curiae to assist the Trial Chamber by raising any defences that Milošević might properly raise based upon the evidence; making a submission as to the relevance, if any, of the NATO air campaign in Kosovo; and identifying any potential witnesses whom the Trial Chamber may wish to call. See Prosecutor v. Milošević 11 January 2002.

${ }^{12}$ These were Ramsey Clark and John Livingston. See Prosecutor v. Milošević 15 November 2001.

${ }^{13}$ Rule 65 (Legal Assistance) of the Rules Governing the Detention of Persons Awaiting Trial or Appeal before the Tribunal or Otherwise Detained on the Authority of the Tribunal reads:(A) Each detainee shall be entitled to communicate fully and without restraint with his legal representative, with the assistance of an interpreter where necessary.(B) All such communications shall be privileged, unless the Registrar has reasonable grounds to believe that the privilege is being abused in an attempt to:i. arrange an escape;ii. interfere with or intimidate witnesses;iii. interfere with the administration of justice; oriv. otherwise endanger the security and safety of the Detention Unit.Prior to such communications being monitored, the detainee and his counsel shall be notified by the Registrar of the reasons for monitoring. The detainee may at any time request the President to reverse any decision made by the Registrar under this Rule.(C) Unless such legal representative and interpreter have been provided by the Tribunal on the basis of the indigency of the detainee, all such communications shall be borne at the expense of the detainee.(D) All such visits shall be made by prior arrangement with the Commanding Officer as to the time and duration of the visit and shall be subject to the same security controls as are imposed under Rule 61. The Commanding Officer shall 
not refuse a request for such a visit without reasonable grounds.(E) Subject to Sub-Rule (B) of this Rule, interviews with legal representatives and interpreters shall be conducted in the sight but not within the hearing, either direct or indirect, of the staff of the Detention Unit.

${ }^{14}$ This followed an oral order of the Trial Chamber denying the request. See T.42 (30 October 2001): "JUDGE MAY: The first matter to deal with this morning is the preliminary motion or preliminary motions. We have taken the opportunity to consider all of them during the adjournment. All will be dismissed, and we shall give our reasons in writing shortly."

${ }^{15}$ Citing Prosecutor v. Tadić 2 October 1995, para. 45

${ }^{16}$ Prosecutor v. Milošević, Case No. IT-99-37-PT, Decision on Preliminary Motions, 8 November 2001, paras. 12-17; Statute of ICTY, Art. 16(2): "[T] he Prosecutor shall act independently as a separate organ of the International Tribunal. He or she shall not seek or receive instructions from any Government or from any other source."

${ }^{17}$ Prosecutor v. Milošević 8 November 2001, paras. 18-22 (citing Prosecutor v. Furundžija 21 July 2000, para. 174).

${ }^{18}$ Citing IT/32/Rev.14, Rule 58.

${ }^{19}$ In addition, the case against Vlajko Stojiljković was dismissed on account of the fact that he had committed suicide on 13 April 2002 in Belgrade. See Prosecutor v. Milošević, Milutinović, Ojdanić, Šainović, and Stojiljković 5 September 2002; ICTY 2003, para. 114.

${ }^{20}$ The Milutinović et al. trial began on 6 July 2006

${ }^{21}$ The Indictment can be found in Attachment A to Prosecutor v. Milošević, Milutinović, Šainović, Ojdanić, and Stojiljković 16 October 2001.

${ }^{22}$ It should be noted that, on 4 November 2002, the Trial Chamber granted the Prosecution leave to amend the Croatia Indictment and ordered that the amended Croatia Indictment be the operative indictment for purposes of the Croatia phase of the proceedings. See Prosecutor v. Milošević 4 November 2002.

${ }^{23}$ See Additional file 1 to this article, which contains the tables of the counts with which Milošević was charged.

${ }^{24}$ Rule 73(D) (13 December 2001) reads:(D) Decisions on all other motions are without interlocutory appeal save with the leave of a bench of three Judges of the Appeals Chamber which may grant such leave(i) if the decision impugned would cause such prejudice to the case of the party seeking leave as could not be cured by the final disposal of the trial including post-judgment appeal;(ii) if the issue in the proposed appeal is of general importance to proceedings before the Tribunal or in international law generally.

${ }^{25}$ Art. 16(2) reads: "The Prosecutor shall act independently as a separate organ of the International Tribunal. He or she shall not seek or receive instructions from any Government or from any other source."
${ }^{26}$ According to that decision, the fact that the Trial Chamber renders a decision proprio motu does not deny the Prosecutor the right to seek leave to appeal pursuant to Rule 73(D), provided that the decision meets the other requirements of Rule 73(D), and does not exclude the application of Rule 73(B) if the decision rendered during the course of the trial is one "involving evidence and procedure". It is only the character of the impugned decision, and not that of its consequences, that determines the application of Rule 73(B). See Prosecutor v. Milošević, 25 April 2002a, paras. 6-7, 12.

${ }^{27}$ The version of Rule 92 bis (entitled "Proof of Facts other than by Oral Evidence") in force at the time of the Milošević Trial (adopted 1 Dec 2000 and 13 Dec 2000) was as follows:(A) A Trial Chamber may admit, in whole or in part, the evidence of a witness in the form of a written statement in lieu of oral testimony which goes to proof of a matter other than the acts and conduct of the accused as charged in the indictment.(i) Factors in favour of admitting evidence in the form of a written statement include but are not limited to circumstances in which the evidence in question:(a) is of a cumulative nature, in that other witnesses will give or have given oral testimony of similar facts; (b) relates to relevant historical, political or military background;(c) consists of a general or statistical analysis of the ethnic composition of the population in the places to which the indictment relates;(d) concerns the impact of crimes upon victims;(e) relates to issues of the character of the accused; or(f) relates to factors to be taken into account in determining sentence.(ii) Factors against admitting evidence in the form of a written statement include whether:(a) there is an overriding public interest in the evidence in question being presented orally;(b) a party objecting can demonstrate that its nature and source renders it unreliable, or that its prejudicial effect outweighs its probative value; or (c) there are any other factors which make it appropriate for the witness to attend for crossexamination.(B) A written statement under this Rule shall be admissible if it attaches a declaration by the person making the written statement that the contents of the statement are true and correct to the best of that person's knowledge and belief and(i) the declaration is witnessed by:(a) a person authorised to witness such a declaration in accordance with the law and procedure of a State; or(b) a Presiding Officer appointed by the Registrar of the Tribunal for that purpose; and(ii) the person witnessing the declaration verifies in writing:(a) that the person making the statement is the person identified in the said statement;(b) that the person making the statement stated that the contents of the written statement are, to the best of that person's knowledge and belief, true and correct; (c) that the person making the statement was informed that if the content of the written 
statement is not true then he or she may be subject to proceedings for giving false testimony; and(d) the date and place of the declaration. The declaration shall be attached to the written statement presented to the Trial Chamber.(C) A written statement not in the form prescribed by paragraph (B) may nevertheless be admissible if made by a person who has subsequently died, or by a person who can no longer with reasonable diligence be traced, or by a person who is by reason of bodily or mental condition unable to testify orally, if the Trial Chamber:(i) is so satisfied on a balance of probabilities; and(ii) finds from the circumstances in which the statement was made and recorded that there are satisfactory indicia of its reliability.(D) A Chamber may admit a transcript of evidence given by a witness in proceedings before the Tribunal which goes to proof of a matter other than the acts and conduct of the accused.(E) Subject to Rule 127 or any order to the contrary, a party seeking to adduce a written statement or transcript shall give fourteen days notice to the opposing party, who may within seven days object. The Trial Chamber shall decide, after hearing the parties, whether to admit the statement or transcript in whole or in part and whether to require the witness to appear for cross-examination.

${ }^{28}$ Judge Kwon issued a declaration expressing his view in relation to the general issue of the admission of witness statements as evidence during trial. Prosecutor v. Milošević 21 March 2002, para. 3 (Declaration of Judge O-Gon Kwon).

${ }^{29}$ It is also to be noted that Judge Kwon dissented.

${ }^{30}$ See Prosecutor v. Milošević 12 January 2004; 9 December 2003. As noted by Human Rights Watch, "[t]he Appeals Chamber's decision marked a major shift in how evidence was presented at the trial." See Human Rights Watch 2006, p. 65. However, the Trial Chamber's interpretation of Rule 89(F) as precluding evidence going to prove the acts and conduct of an accused was to be "overturned" as well, with the codification of the Appeals Chamber's decision in Rule 92 ter. On 13 September 2006, the judges adopted Rule 92 ter (entitled "Other Admission of Written Statements and Transcripts"), which provides as follows:(A) A Trial Chamber may admit, in whole or in part, the evidence of a witness in the form of a written statement or transcript of evidence given by a witness in proceedings before the Tribunal, under the following conditions:(i) the witness is present in court;(ii) the witness is available for crossexamination and any questioning by the Judges; and(iii) the witness attests that the written statement or transcript accurately reflects that witness' declaration and what the witness would say if examined.(B) Evidence admitted under paragraph (A) may include evidence that goes to proof of the acts and conduct of the accused as charged in the indictment. Following this codification, the President of the Tribunal, in his biannual report to the UN Security Council, delivered on 7 June 2006, stated that, "[t]he introduction of Rule 92ter, which authorizes a Trial Chamber under certain conditions to consider written statements and transcripts of witnesses in lieu of oral testimony that goes to proof of the acts and conduct of the accused, has also had a significant impact on proceedings at the International Tribunal." After giving a specific example, the President report to the UN Security Council that it was "clear that a substantial savings of court time is resulting from the use of Rule 92ter." See Pocar 2007, para. 11. Human Rights Watch has generally concurred with the above assessment, while cautioning that the virtual elimination of direct examination of a witness may reduce the judges' ability to assess his or her credibility and recommending that the public be furnished with copies of the statements of a witness in advance of the testimony, so the witness's evidence can be easily followed and understood by the public. See Human Rights Watch 2006, pp. 65-67.

${ }^{31}$ On 9 May 2002, the Amici Curiae opposed the motion. See Prosecutor v. Milošević 9 May 2002.

${ }^{32}$ Prosecutor v. Milošević 12 December 2002a, para.1. On 6 February 2003, the Amici Curiae opposed the motion. See Prosecutor v. Milošević 12 December 2002b.

${ }^{33}$ Rule 70 (entitled "Matters not Subject to Disclosure"), published in the version of 13 December 2001, reads:(A) Notwithstanding the provisions of Rules 66 and 67 , reports, memoranda, or other internal documents prepared by a party, its assistants or representatives in connection with the investigation or preparation of the case, are not subject to disclosure or notification under those Rules.(B) If the Prosecutor is in possession of information which has been provided to the Prosecutor on a confidential basis and which has been used solely for the purpose of generating new evidence, that initial information and its origin shall not be disclosed by the Prosecutor without the consent of the person or entity providing the initial information and shall in any event not be given in evidence without prior disclosure to the accused. (Amended 4 Oct 1994, revised 30 Jan 1995, revised 12 Nov 1997)(C) If, after obtaining the consent of the person or entity providing information under this Rule, the Prosecutor elects to present as evidence any testimony, document or other material so provided, the Trial Chamber, notwithstanding Rule 98, may not order either party to produce additional evidence received from the person or entity providing the initial information, nor may the Trial Chamber for the purpose of obtaining such additional evidence itself summon that person or a representative of that entity as a witness or order their attendance. A Trial Chamber may not use its power to order the attendance of 
witnesses or to require production of documents in order to compel the production of such additional evidence. (Amended 6 Oct 1995, amended 25 July 1997)(D) If the Prosecutor calls a witness to introduce in evidence any information provided under this Rule, the Trial Chamber may not compel that witness to answer any question relating to the information or its origin, if the witness declines to answer on grounds of confidentiality. (Amended 6 Oct 1995, amended 25 July 1997)(E) The right of the accused to challenge the evidence presented by the Prosecution shall remain unaffected subject only to the limitations contained in paragraphs $(C)$ and (D). (Amended 6 Oct 1995, amended 12 Apr 2001)(F) The Trial Chamber may order upon an application by the accused or defence counsel that, in the interests of justice, the provisions of this Rule shall apply mutatis mutandis to specific information in the possession of the accused. (Amended 25 July 1997)(G) Nothing in paragraph (C) or (D) above shall affect a Trial Chamber's power under Rule 89(D) to exclude evidence if its probative value is substantially outweighed by the need to ensure a fair trial. (Amended 6 Oct 1995, amended 12 Apr 2001).

${ }^{34}$ The FRY changed its name to "Serbia and Montenegro" on 4 February 2003. See Prosecutor v. Milošević 7 February 2003, p. 2, note 1.

${ }^{35}$ See also Prosecutor v. Blaškić 10 April 1997, pp. 5-18.

${ }^{36}$ Rule 54 bis (entitled "Orders Directed to States for the Production of Documents") published in the 13 December 2001 version reads:(A) A party requesting an order under Rule 54 that a State produce documents or information shall apply in writing to the relevant Judge or Trial Chamber and shall:(i) identify as far as possible the documents or information to which the application relates;(ii) indicate how they are relevant to any matter in issue before the Judge or Trial Chamber and necessary for a fair determination of that matter; and,(iii) explain the steps that have been taken by the applicant to secure the State's assistance.(B) The Judge or Trial Chamber may reject an application under paragraph (A) in limine if satisfied that:(i) the documents or information are not relevant to any matter in issue in the proceedings before them or are not necessary for a fair determination of any such matter; or(ii) no reasonable steps have been taken by the applicant to obtain the documents or information from the State.(C) A decision by a Judge or a Trial Chamber under paragraph (B) or (E) shall be subject to appeal with the leave of a bench of three Judges of the Appeals Chamber on the same grounds and conditions as set out in Rule 73(D) and (E).(D)(i) Except in cases where a decision has been taken pursuant to paragraph (B) or paragraph (E), the State concerned shall be given notice of the application, and not less than fifteen days' notice of the hearing of the application, at which the State shall have an opportunity to be heard.(ii) Except in cases where the Judge or Trial Chamber determines otherwise, only the party making the application and the State concerned shall have the right to be heard.(E) If, having regard to all circumstances, the Judge or Trial Chamber has good reasons for so doing, the Judge or Trial Chamber may make an order to which this Rule applies without giving the State concerned notice or the opportunity to be heard under paragraph (D), and the following provisions shall apply to such an order:(i) the order shall be served on the State concerned;(ii) subject to paragraph (iv), the order shall not have effect until fifteen days after such service;(iii) a State may, within fifteen days of service of the order, apply by notice to the Judge or Trial Chamber to have the order set aside, on the grounds that disclosure would prejudice national security interests.Paragraph (F) shall apply to such a notice as it does to a notice of objection;(iv) where notice is given under paragraph (iii), the order shall thereupon be stayed until the decision on the application;(v) paragraphs (F) and (G) shall apply to the determination of an application made pursuant to paragraph (iii) as they do to the determination of an application of which notice is given pursuant to paragraph (D);(vi) the State and the party who applied for the order shall, subject to any special measures made pursuant to a request under paragraphs (F) or (G), have an opportunity to be heard at the hearing of an application made pursuant to paragraph (E)(iii) of this Rule.(F) The State, if it raises an objection pursuant to paragraph (D), on the grounds that disclosure would prejudice its national security interests, shall file a notice of objection not less than five days before the date fixed for the hearing, specifying the grounds of objection. In its notice of objection the State:(i) shall identify, as far as possible, the basis upon which it claims that its national security interests will be prejudiced; and(ii) may request the Judge or Trial Chamber to direct that appropriate protective measures be made for the hearing of the objection, including in particular:(a) hearing the objection in camera and ex parte;(b) allowing documents to be submitted in redacted form, accompanied by an affidavit signed by a senior State official explaining the reasons for the redaction;(c) ordering that no transcripts be made of the hearing and that documents not further required by the Tribunal be returned directly to the State without being filed with the Registry or otherwise retained.(G) With regard to the procedure under paragraph $(\mathrm{F})$ above, the Judge or Trial Chamber may order the following protective measures for the hearing of the objection:(i) the designation of a single Judge from a Chamber to examine the documents or hear submissions; and/or(ii) that the State be allowed to provide its own interpreters for the hearing and its own translations of sensitive 
documents. $(\mathrm{H})$ Rejection of an application made under this Rule shall not preclude a subsequent application by the requesting party in respect of the same documents or information if new circumstances arise.(I) An order under this Rule may provide for the documents or information in question to be produced by the State under appropriate arrangements to protect its interests, which may include those arrangements specified in paragraphs (F)(ii) or (G).Once documents have been produced to a party by a State pursuant to an order under Rule 54 bis, they can be used in different manners. Such documents may in general inform a party's preparation for trial, but oftentimes, a party will want to tender as evidence a document received by a State. It is then that the party must demonstrate that the document is susceptible to being admitted into evidence at trial pursuant to Rule $89(\mathrm{C})$, which provides, "A Chamber may admit any relevant evidence which it deems to have probative value." See IT/32/REV.21: Rule $89($ C). This is by no means a pro forma matter, because it is only after documents are admitted into evidence that they form part of the record of the trial and thus can be taken into account for purposes of the judges' deliberations and final judgement. Moreover, documents obtained from a State can often be considered to have a high degree of reliability, thus possessing a high probative value.

${ }^{37}$ Stating that the Prosecution had issued 57 document requests in connection with the Milošević trial, of which 32 were still pending, Prosecutor v. Milošević 13 December 2002, paras. 8-10 (requesting access to archives).

${ }^{38}$ Art. 18(2): The Prosecutor shall have the power to question suspects, victims and witnesses, to collect evidence and to conduct on-site investigations. In carrying out these tasks, the Prosecutor may, as appropriate, seek the assistance of the State authorities concerned."; Rule 39:"In the conduct of an investigation, the Prosecutor may: (i) summon and question suspects, victims and witnesses and record their statements, collect evidence and conduct on-site investigations; (ii) undertake such other matters as may appear necessary for completing the investigation and the preparation and conduct of the prosecution at the trial, including the taking of special measures to provide for the safety of potential witnesses and informants; (iii) seek, to that end, the assistance of any State authority concerned, as well as of any relevant international body including the International Criminal Police Organization (INTERPOL); and (iv) request such orders as may be necessary from a Trial Chamber or a Judge."

${ }^{39}$ Arguing, inter alia, that requests for access to archives reveal logical inconsistency with specificity requirement.

${ }^{40}$ Rule 54: "At the request of either party or proprio motu, a Judge or a Trial Chamber may issue such orders, summonses, subpoenas, warrants and transfer orders as may be necessary for the purposes of an investigation or for the preparation or conduct of the trial."

${ }^{41}$ The second decision was initially issued on a confidential basis but subsequently made public. See Prosecutor v. Milošević 15 September 2003, note 3; 18 June 2003.

${ }^{42}$ See, e.g. Prosecutor v. Milošević 16 January 2004; 17 February 2004 (reporting on efforts to locate financial documentation from the Ministry of Finance and Economy of Republic of Serbia, documentation relating to Joint Command for Kosovo, documentation related to Novi Sad Corps, letter from Radovan Karadžić to Zoran Lilić regarding dismissal of generals of Bosnia Serb Army, and documentation relating to training of volunteers in special units of the Yugoslav Army); 23 February 2004 (reporting further on financial documentation).

${ }^{43}$ These were Zdenko Tomanović and Dragoslav Ognjanović. See Hearing 10 April 2002, T.2797.

${ }^{44}$ This was Branko Rakić, Senior Lecturer at the Faculty of Law at the University of Belgrade. See Prosecutor v. Milošević 23 October 2003b.

${ }^{45}$ This was Professor Mischa Wladimiroff. See Prosecutor v. Milošević 10 October 2002, p. 4.

${ }^{46}$ This was Professor Timothy McCormack from Australia. See Prosecutor v. Milošević 22 November 2002a.

${ }^{47}$ For a comprehensive substantive discussion on judicial decisions regarding self-representation, see Boas 2006.

${ }^{48}$ The Trial Chamber was informed by United Nations Detention Unit that Milošević would not be present in court that day because he had complained of exhaustion and that a medical report was being obtained. Hearing 1 November 2002, T.12727. Milošević had previously been unable to attend court due to ill health on 18-28 March 2002, 17-27 June 2002, and 18-19 July 2002.

${ }^{49}$ Rule 80 (Control of Proceedings) reads:(A) The Trial Chamber may exclude a person from the courtroom in order to protect the right of the accused to a fair and public trial, or to maintain the dignity and decorum of the proceedings.(B) The Trial Chamber may order the removal of an accused from the courtroom and continue the proceedings in the absence of the accused if the accused has persisted in disruptive conduct following a warning that such conduct may warrant the removal of the accused from the courtroom.

${ }^{50} \mathrm{An}$ example of some of these documents, subject to the admission of which the Prosecution had closed its case, were the minutes and stenographic notes of the FRY's Supreme Defence Council. In June 2004, after the close of the Prosecution case and before the start of the defence case, the Chamber issued a decision finding that the Prosecution had demonstrated the relevance of two 
sessions of the SDC materials, granting permission for them to be admitted into evidence, and noting that it would issue another decision with respect to the remainder of the SDC materials in due course. See Prosecutor v. Milošević 23 September 2004a, pp. 2-4 (noting that the Trial Chamber issued a confidential version of its decision on 11 June 2004). In September, the Chamber issued its second decision with respect to the admissibility of the SDC materials, in which it granted admission to the remainder of the SDC materials. See Prosecutor v. Milošević 23 September 2004b, p. 4.

${ }^{51}$ For a comprehensive analysis of the motion for judgment for acquittal, see Gaparayi 2004, pp. 737-766.

${ }^{52}$ In respect of the allegations challenged by the Amici Curiae in the three indictments, the Prosecution conceded that for some of them there was no or insufficient evidence to meet the legal standard required under Rule 98 bis and did not object to a judgment of acquittal being entered in respect of these allegations. However, many of the challenges were not conceded by the Prosecution. See Prosecutor v. Milošević 3 May 2004, p. 25, et seq (Kosovo), p. 61, et seq (Croatia), and p. 174, et seq (Bosnia).

${ }^{53}$ The Indictment can be found in Annex A of Prosecutor v. Milošević 22 November 2002b.

${ }^{54}$ The Indictment can be found attached to Prosecutor v. Milošević 26 July 2004a.

${ }^{55}$ Noting that pro se liaison officer had filed submission on behalf of Milošević requesting admission of documents tendered as evidence through witness Obrad Stevanović and setting forth arguments in support of their admission into evidence.

${ }^{56}$ Requiring also Registrar to identify counsel who might be assigned to case.

${ }^{57}$ See Rule $90(\mathrm{H})$ of the 13 December 2001 version reads:(i) Cross-examination shall be limited to the subject-matter of the evidence-in-chief and matters affecting the credibility of the witness and, where the witness is able to give evidence relevant to the case for the cross-examining party, to the subject-matter of that case.(ii) In the cross-examination of a witness who is able to give evidence relevant to the case for the crossexamining party, counsel shall put to that witness the nature of the case of the party for whom that counsel appears which is in contradiction of the evidence given by the witness.(iii) The Trial Chamber may, in the exercise of its discretion, permit enquiry into additional matters.

${ }^{58}$ Citing, in a "compare" signal, Prosecutor v. Blaškić 29 October 1997, para. 68 (citing New Zealand v. France, p. 268, para. 46).

${ }^{59}$ Hearing 15 November 2005, T.46481-46484 (Milošević noted that these three physicians were "professionals from Russia, France, and Serbia”).

${ }^{60}$ These reports were filed confidentially, but their existence and the fact that they were filed before the
Trial Chamber is a matter of public record. See Hearing 15 November 2005, T.46481-46484 (discussion of procedural matters in open session).

${ }^{61}$ The Prosecution filed an Interim Response on 22 December 2005; see Prosecutor v. Milošević 22 December 2005a; see also Prosecutor v. Milošević 22 December 2005b.

${ }^{62}$ Although the attachments themselves are confidential, they are described in the Second Addendum, which was filed publicly. See Second Addendum, para 5.

${ }^{63}$ See, e.g. Hearing 02 September 2004, T.25953: "JUDGE MAY: Well, he has shown in cross-examination that he has a great deal of material available to him, very detailed cross-examination of a lot of witnesses, which must have been based on material." Later, during the defence phase of the case, the Trial Chamber remarked that Milošević could receive and send uncensored mail and facsimile messages from and to his Legal Associates on weekdays, conduct unmonitored communications by telephone with his Legal Associates during all days of the week, receive scheduled visits of his Legal Associates during weekdays, make use of the photocopying facilities of the UNDU, review video evidence on VCR at the UN Detention Unit, use his own portable computer in the UN Detention Unit, and, if he so wished, install a printer to it. Prosecutor v. Milošević 22 September 2004, para. 65. While appearing in court, Milošević was allowed to access a privileged phone line during the trial breaks and could send facsimiles and use photocopying facilities if urgently needed. Prosecutor v. Milošević 12 December 2005, p. 10, note 49.

${ }^{64}$ For a critical discussion, see Grosscup 2004, p. 355; Steinitz 2005, pp. 103-123; Harvard International Review 2006.

\section{Additional files}

Additional file 1: Tables of "Counts". The file contains the tables of the counts with which Milošević was charged. (PDF 97.3 kb)

Additional file 2: Quantitative data on evidence. Notwithstanding the Trial Chamber's denial of the Prosecution's motion to reopen its casein-chief in relation to the Bosnia and Kosovo indictments in December 2005 (in January 2006, the Chamber denied the Prosecution's motion for certification of an interlocutory appeal of this decision; Prosecutor $\mathrm{v}$. Milošević 18 January 2006), by the time the trial was terminated, a prodigious amount of evidence had been presented by both parties, in addition to 49,191 pages of transcripts. The tables in the file attempt to capture the sheer volume of the evidence. (PDF $97.4 \mathrm{~kb}$ )

Competing interests

The authors declare that they have no competing interests.

Authors' contributions

The views expressed herein are those of the authors alone and do not necessarily reflect the views of the OPCW, ICC, ICTY, or the United Nations in general. Both authors read and approved the final manuscript.

Acknowledgements

The title of this article borrows from the seminal book of Taylor (1992). 


\section{Author details}

${ }^{1}$ Presidency Legal and Enforcement Unit, International Criminal Court, Oude Waalsdorperweg 10, 2597 AK The Hague, The Netherlands. ${ }^{2}$ Organisation for the Prohibition of Chemical Weapons, Johan de Wittlaan 32, 2517 JR The Hague, The Netherlands.

Received: 25 November 2015 Accepted: 5 January 2016

Published online: 01 March 2016

\section{References}

"Milošević Motion" (untitled document filed by the accused) (30 August 2001)

Addendum to "Prosecution Submission in Response to the Trial Chamber's 19 July 2004' Further Order on Future Conduct of the Trial'" and also to "Prosecution Submission in Response to the Trial Chamber's 21 July 2004 'Further Order on Future Conduct of the Trial Relating to Severance of One or more Indictments'" (6 August 2004)

Application of the Convention on the Prevention and Punishment of the Crime of Genocide (Bosnia and Herzegovina v. Serbia and Montenegro) (Judgment) 2007. http://www.icj-cij.org/docket/files/91/13685.pdf. Accessed 8 Nov 2015

BBC (2001a) Milosevic gets birthday visit, 20 August., http://news.bbc.co.uk/1/hi/ world/europe/1500676.stm. Accessed 15 Jul 2009

BBC (2001b) Milosevic wife makes prison visit. 19 July., http://news.bbc.co.uk/2/ hi/europe/1443021.stm. Accessed 15 July 2009

BBC (2006) Milošević buried in his hometown. 18 March. http://news.bbc.co.uk/2/ hi/europe/4819158.stm. Accessed 11 Oct 2015

Boas $G$ (2006) The right to self-representation in international and domestic criminal law-limitations and qualifications on that right. In: The dynamics of international criminal justice. Essays in honours of Sir Richard May. Martinus Nijhoff Publishers, Leiden

del Ponte C (2002) ICTY, Address by the Prosecutor of the International Criminal Tribunals for the former Yugoslavia and Rwanda. Mrs. Carla del Ponte, to the United Nations Security Council (30 October 2002) JJJ/P.I.S./709-e

Featherstone Y (2006) Sir Richard May: A Personal Reflection. In: Abtahi H, Boas G (eds) The dynamics of international criminal justice. Essays in honour of Sir Richard May. Martinus Nijhoff Publishers, Leiden

Gaparayi I (2004) The Milošević trial at the halfway stage: Judgement on the motion for acquittal. Leiden Journal of International Law 17:737-766

Grosscup S (2004) The trial of Slobodan Milosevic: The demise of head of state immunity and the specter of victor's justice. Denver J Int'l L \& Policy 32:355

Harvard International Review (2006) Credibility and legitimacy of international criminal tribunals in the wake of Milosevic's death. In Harvard International Review. http://hir.harvard.edu/credibility-and-legitimacy-of-internationalcriminal-tribunals-in-the-wake-of-milosevics-death/. Accessed 27 Nov 2006

Hearing (02 September 2004)

Hearing (11 November 2002)

Hearing (10 April 2002)

Hearing (10 March 2003)

Hearing (12 December 2005)

Hearing (15 November 2005)

Hearing (18 December 2002)

Hearing (2 February 2006)

Hearing (24 April 2002)

Hearing (27 September 2002)

Hearing (30 May 2002)

Hearing (30 September 2002)

Hearing (31 August and 1 September 2004)

Hearing (5 July 2004)

Hearing, 11 December 2001, T. 32 (Bosnia)

Human Rights Watch (2006) Weighing the evidence, lessons from the Slobodan Milosevic trial. 18(10(D))

ICTY (2003) Tenth Annual Report of the International Tribunal for the Prosecution of Persons Responsible for Serious Violations of International Humanitarian Law Committed in the Territory of the Former Yugoslavia since 1991 to the United Nations Security Council

ICTY case information sheet, http://www.icty.org/x/cases/slobodan_milosevic/cis/ en/cis_milosevic_slobodan.pdf. Accessed 15 Jul 2009

IT/32/REV.21 Rules of Procedure and Evidence of the International Criminal Tribunal for the former Yugoslavia (adopted 1994)
Jorda C (2002) ICTY, Address by His Excellency, Judge Claude Jorda, President of International Criminal Tribunal for the former Yugoslavia, to the United Nations Security Council (30 October 2002) JDH/P.IS./708-e

Judah T (2002) Kosovo, war and revenge. Yale University Press, New Haven

Langer M (2005) The rise of managerial judging in international criminal law. Am J Comp L 53:835

Lillian Goldman Law Library (2008) Judgement Doenitz. http://avalon.law.yale. edu/imt/juddoeni.asp. Accessed 04 Sept 2015

Prosecutor v Milošević, Case No. IT-99-37-PT, Amici Curiae Brief on Jurisdiction, 19 October 2001, at paras. 35-51 (citing Rule 58, Rules of Procedure and Evidence, IT/32/Rev.14)

Motion Hearing (Croatia) (29 October 2001)

Nuclear Tests case (New Zealand v. France), I.C.J. Reports 1974

Parker K (2006) 'Report to the president, death of Slobodan Milošević'., 30 May 2006. http://www.icty.org/x/cases/slobodan_milosevic/custom2/en/ parkerreport.pdf. Accessed 8 Nov 2015

Pocar F (2007) 'Letter dated 15 May 2007 from the President of the International Tribunal for the Prosecution of Persons Responsible for Serious Violations of International Humanitarian Law Committed in the Territory of the Former Yugoslavia since 1991, addressed to the President of the Security Council' (16 May 2007) S/2007/283

Prosecutor v. Blagojević (Public and Redacted Reasons for Decision on Appeal by Vidoje Blagojević to Replace his Defence Team) IT-02-60-AR73.4 (7 November 2003)

Prosecutor v. Blaškić (Amicus curiae Brief Submitted by the Max-Planck-Institute for Comparative Public Law and International Law (Max-Planck-Institut für ausländisches öffentliches Recht und Völkerrecht) Heidelberg, Germany to the International Criminal Tribunal for the Former Yugoslavia in the Case of The Prosecutor v. Tihomir Blaškić) IT-95-14-PT, pursuant to the order inviting amicus curiae briefs of 14 March 1997, IT-95-14-PT (10 April 1997)

Prosecutor v. Blaškić (Judgement on the Request of the Republic of Croatia for Review of Trial Chamber II of 18 July 1997) IT-95-14-A R108bis (29 October 1997)

Prosecutor v. Furundžija (Judgment) IT-05-17/1-A (21 July 2000)

Prosecutor v. Karadžić (Decision on Interlocutory Appeal of the Trial Chamber's Decision on Adequate Facilities) IT-95-5/18-AR73.2 (7 May 2009)

Prosecutor v. Krajišnik (Decision on Krajišnik Request and on Prosecution Motion) IT-00-39-A (11 September 2007)

Prosecutor v. Milošević ("Prosecution Motion to Amend the Bosnia Indictment with Confidential Annex B") IT-02-54-T (22 November 2002b)

Prosecutor v. Milošević (Amici Curiae Brief on Jurisdiction) IT-99-37-PT (19 October 2001)

Prosecutor v. Milošević (Amici Curiae Motion for Judgement of Acquittal Pursuant to Rule 98 bis) IT-02-54-T (3 March 2004)

Prosecutor v. Milošević (Amici Curiae Observations on the "Prosecution Notice of Adjudicated Facts,") IT-02-54-T (12 December 2002b)

Prosecutor v. Milošević (Amici Curiae Response to the Prosecution Motion on Joinder) IT-99-37-PT, IT-01-50-PT, and IT-01-51-I (5 December 2001)

Prosecutor v. Milošević (Amici Curiae Submissions in Response to the Trial Chamber's 'Further Order on Future Conduct of the Trial Concerning Assignment of Defence Counsel' dated 6 August 2004") (13 August 2004)

Prosecutor v. Milošević (Amici Curiae Submissions in Response to Trial Chamber Further Decision on Prosecution Motion for Judicial Notice of Adjudicated Facts Dated 6 November 2003) IT-02-54-T (18 November 2003)

Prosecutor v. Milošević (Amici Curiae Submissions on the Trial Chamber's Further Order on Future Conduct of the Trial Relating to Severance of One or More Indictments dated 21 July 2004) (27 July 2004b)

Prosecutor v. Milošević (Application for Limited Re-Opening of the Bosnia and Kosovo Components of the Prosecution Case) IT-02-54-T (18 July 2005)

Prosecutor v. Milošević (Brief on the Provision of Adequate Facilities to Allow the Accused to Prepare his Defence) IT-02-54-T (5 March 2002)

Prosecutor v. Milošević (Decision Affirming the Registrar's Denial of Assigned Counsel's Application to Withdraw) IT-02-54-T (7 February 2005a)

Prosecutor v. Milošević (Decision Concerning an Amicus Curiae) IT-02-54-T (10 October 2002)

Prosecutor v. Milošević (Decision in Part on Prosecution Motion for Orders Pursuant to Rule 54bis Against Serbia and Montenegro) IT-02-54-T (5 June 2003)

Prosecutor v. Milošević (Decision in Relation to Severance, Extension of Time and Rest) IT-02-54-T (12 December 2005)

Prosecutor v Milošević (Decision in Relation to Severance, Extension of Time and Rest) IT-02-54-T (13 December 2005a) 
Prosecutor v. Milošević (Decision on Admissibility of Prosecution Investigator's Evidence) IT-02-54-AR73.2 (30 September 2002)

Prosecutor v. Milošević (Decision on Admission of Documents in Connection with Testimony of Defence Witness Obrad Stevanović) IT-02-54-T (8 July 2005)

Prosecutor v. Milošević (Decision on Application for a Limited Re-Opening of the Bosnia and Kosovo Components of the Prosecution Case) IT-02-54-T (13 December 2005b)

Prosecutor v. Milošević (Decision on Assigned Counsel Application for Interview and Testimony of Tony Blair and Gerhard Schröder) IT-02-54-T (9 December 2005)

Prosecutor v. Milošević (Decision on Assigned Counsel Request for Provisional Release) IT-02-54-T (23 February 2006)

Prosecutor v. Milošević (Decision on Assigned Counsel's Motion for Withdrawal) IT-02-54-T (7 December 2004)

Prosecutor v. Milošević (Decision on Confidential Prosecution Motion for Admission of a Transcript and Statement Pursuant to Rules 92 bis(D) and 89(F) for Witness B-1805) IT-02-54-T (12 January 2004)

Prosecutor v. Milošević (Decision on Interlocutory Appeal on the Admissibility of Evidence-in-Chief in the Form of Written Statements) IT-02-54-AR73.4 (20 September 2003)

Prosecutor v. Milošević (Decision on Motion for Judgement of Acquittal) IT-02-54$\mathrm{T}$ (16 June 2004)

Prosecutor v. Milošević (Decision on Notification of the Completion of Prosecution Case and Motion for the Admission of Evidence in Written Form) IT-02-54-T (25 February 2004b)

Prosecutor v. Milošević (Decision on Preliminary Motions) IT-99-37-PT (8 November 2001)

Prosecutor v. Milošević (Decision on Prosecution Application for Further Action in Relation to Previous Rule 54bis Applications) IT-02-54-T (31 October 2005)

Prosecutor v. Milošević (Decision on Prosecution Interlocutory Appeal from Refusal to Order Joinder) IT-99-37-AR73; IT-01-50-AR73; and IT-01-51-AR73 (1 February 2002)

Prosecutor v. Milošević (Decision on Prosecution Motion for Admission of Witness Declaration of Tore Soldal Pursuant to Rule 89(F)) IT-02-54-T ( 9 December 2003)

Prosecutor v. Milošević (Decision on Prosecution Motion for Judicial Notice of Adjudicated Facts) IT-02-54-T (10 April 2003)

Prosecutor v. Milošević (Decision on Prosecution Motion for Reconsideration Regarding Evidence of Defence Witnesses Mitar Balević, Vladislav Jovanović, Vukašin Andrić, and Dobre Aleksovski and Decision Proprio Motu Reconsidering Admission of Exhibits 837 and 838 Regarding Evidence of Defence Witness Barry Lituchy) IT-02-54-T (17 May 2005)

Prosecutor v. Milošević (Decision on Prosecution Motion for the Admission of Evidence-in-Chief of its Witnesses in Writing) IT-02-54-T (16 April 2003)

Prosecutor v. Milošević (Decision on Prosecution Motion for the Admission of Transcripts in Lieu of Viva Voce Testimony Pursuant to 92 bis (D)_Foča Transcripts) IT-02-54-T (30 June 2003)

Prosecutor v. Milošević (Decision on Prosecution's Motion for Joinder) IT-99-37PT; IT-01-50-PT; and IT-01-51-PT (13 December 2001)

Prosecutor v. Milošević (Decision on Prosecution's Motion for Judicial Notice of Adjudicated Facts Relevant to the Municipality of Brčko) IT-02-54-T (5 June 2002)

Prosecutor v. Milošević (Decision on Prosecution's Request to have Written Statements Admitted under Rule 92 bis) IT-02-54-T (21 March 2002)

Prosecutor v. Milošević (Decision on Prosecution's Request for Certification of Appeal under Rule 73(B)) IT-02-54-T (18 January 2006)

Prosecutor v. Milošević (Decision on Review of Indictment) IT-01-51-1 (22 November 2001)

Prosecutor v. Milošević (Decision on Serbia and Montenegro's Motion to Vacate or Suspend 9 March 2006 Decision and Request to Redact Parts of Public Version of Decision) IT-02-54-T (12 April 2006)

Prosecutor v. Milošević (Decision on the Interlocutory Appeal by the Amici Curiae against the Trial Chamber Order Concerning the Presentation and Preparation of the Defence Case) IT-02-54-AR73.6 (20 January 2004)

Prosecutor v. Milošević (Decision on the Prosecution Application for Leave to File an Interlocutory Appeal) IT-02-54-AR73 (25 April 2002a)

Prosecutor v. Milošević (Decision on the Prosecutor's Interlocutory Appeal Against the Trial Chamber's 10 April 2003 "Decision on Prosecution Motion for Judicial Notice of Adjudicated Facts") IT-02-54-AR73.5 (28 October 2003)
Prosecutor v. Milošević (Decision on Two Prosecution Requests for Certification of Appeal against Decisions of the Trial Chamber) IT-02-54-T (6 May 2003a)

Prosecutor v. Milošević (Decision) IT-02-54-T (14 December 2004)

Prosecutor v. Milošević (Final Decision on Admissibility of Intercepted Communications) IT-02-54-T (14 June 2004)

Prosecutor v. Milošević (Final Decision on Prosecution Motion for Judicial Notice of Adjudicated Facts) IT-02-54-T (16 December 2003a)

Prosecutor v. Milošević (First Addendum to Assigned Counsel Request for Provisional Release pursuant to Rule 65 with Confidential Attachment D) IT-02-54-T (22 December 2005b)

Prosecutor v. Milošević (Further Decision on Prosecution Motion for Judicial Notice of Adjudicated Facts) IT-02-54-T (6 November 2003)

Prosecutor v. Milošević (Further Order on Future Conduct of the Trial Relating to Severance of One or More Indictments) IT-02-54-T (21 July 2004)

Prosecutor v. Milošević (Further Order on Future Conduct of the Trial) IT-02-54-T (19 July 2004)

Prosecutor v. Milošević (Further Order on Medical Examination of the Accused) IT-02-54-T (15 July 2004)

Prosecutor v. Milošević (Hearing) IT-02-54-T (3 June 2003)

Prosecutor v. Milošević (Hearing, Pre-Defence Conference) (2 September 2003)

Prosecutor v. Milošević (Initial Appearance) IT-99-37-I (3 July 2001b)

Prosecutor v. Milošević (Motion Hearing) IT-99-37-AR73, IT-01-50-AR73, IT-01-51AR73 (11 December 2001)

Prosecutor v. Milošević (Observations by the Amici Curiae on the Imposition of Defence Counsel on Accused) IT-02-54-T (18 November 2002)

Prosecutor v. Milošević (Omnibus Order On Matters Dealt With at the Pre-Defence Conference) IT-02-54-T (17 June 2004)

Prosecutor v. Milošević (Oral Ruling by the Trial Chamber) IT-02-54-T (30 September 2003)

Prosecutor v. Milošević (Order Appointing Amicus Curiae) IT-02-54-T (22 November 2002a)

Prosecutor v. Milošević (Order Appointing Branko Rakić as Legal Associate to Accused) IT-02-54-T (23 October 2003b)

Prosecutor v. Milošević (Order Concerning Amici Curiae) IT-99-37-PT (11 January 2002)

Prosecutor v. Milošević (Order Concerning Prosecution Motion Concerning the Implications of the Accused's Health) IT-02-54-T (24 September 2003)

Prosecutor v. Milošević (Order Concerning the Preparation and Presentation of the Defence Case) IT-02-54-T (17 September 2003)

Prosecutor v. Milošević (Order Concerning the Provision of Documents to Amici Curiae) IT-99-37-PT (19 September 2001)

Prosecutor v. Milošević (Order Confirming an Indictment) IT-01-50-I (8 October 2001)

Prosecutor v. Milošević (Order for Commencement of Trial) IT-02-54-PT (4 February 2002)

Prosecutor v. Milošević (Order for Detention on Remand) IT-99-37-I (3 July 2001a)

Prosecutor v. Milošević (Order Granting Leave to Amend the Croatia Indictment) IT-02-54-T (4 November 2002)

Prosecutor v. Milošević (Order Inviting Designation of Amicus Curiae) IT-01-51-PT (30 August 2001b)

Prosecutor v. Milošević (Order of the President Assigning a Case To a Trial Chamber) IT-01-50-I (9 October 2001)

Prosecutor v. Milošević (Order of the President Assigning a Case to a Trial Chamber) IT-01-51-I (23 November 2001b)

Prosecutor v. Milošević (Order of the President on the Composition of a Trial Chamber for a Case) IT-99-37-PT (23 November 2001a)

Prosecutor v. Milošević (Order on Admission of Documents (Including Exhibits of Witnesses Kosta Mihajlović and Čedomir Popov) and Decision on Prosecution Motion Regarding Exhibits and Other Practicalities During the Defence Case) IT-02-54-T (7 February 2005b)

Prosecutor v. Milošević (Order on Amici Curiae Request Concerning the Manner of their Future Engagement and Procedural Directions under Rule 92bis) IT-02-54-T (27 June 2003)

Prosecutor v. Milošević (Order on Future Conduct of the Trial) IT-02-54-T (6 July 2004)

Prosecutor v. Milošević (Order on Prosecution Filing of Amended Annex I to Croatia Indictment) IT-02-54-T (11 March 2004)

Prosecutor v. Milošević (Order on Prosecution Request for Leave to File Reply) IT-02-54-T (19 February 2003)

Prosecutor v. Milošević (Order on the Amended Bosnia Indictment) IT-02-54-T (21 April 2004) 
Prosecutor v. Milošević (Order on the Modalities to be Followed by Court Assigned Counsel) IT-02-54-T (3 September 2004)

Prosecutor v. Milošević (Order Replacing a Judge in a Case before a Trial Chamber) IT-02-54-T (10 June 2004)

Prosecutor v. Milošević (Order Re-Scheduling and Setting the Time Available to Present the Defence Case) IT-02-54-T (25 February 2004C)

Prosecutor v. Milošević (Order Terminating the Proceedings) IT-02-54-T (14 March 2006)

Prosecutor v. Milošević (Order) IT-02-54-T (16 April 2002b)

Prosecutor v. Milošević (Order) IT-99-37-PT (15 November 2001)

Prosecutor v. Milošević (Preliminary Decision on the Admissibility of Intercepted Communications) IT-02-54-T (16 December 2003b)

Prosecutor v. Milošević (Preliminary Order on Assigned Counsel Request for Provisional Release for the Accused) IT-02-54-T (11 January 2006)

Prosecutor v. Milošević (Prosecution Application for Further Action in Relation to Previous Rule 54bis Applications) IT-02-54-T (24 August 2005)

Prosecutor v. Milošević (Prosecution Application to Modify the "Second Order Granting Leave to Amend the Croatia Indictment", and to Permit the Prosecution to File a Second Amended Croatia Indictment") IT-02-54-T (26 July 2004a)

Prosecutor v. Milošević (Prosecution Motion for a Hearing to Discuss the Implications of the Accused's Recurring III Health) IT-02-54-T (23 September 2003)

Prosecutor v. Milošević (Prosecution Motion for Judicial Notice of Adjudicated Facts Relevant to the Municipality of Brčko) IT-02-54-T (25 April 2002b)

Prosecutor v. Milošević (Prosecution Motion for Judicial Notice of Adjudicated Facts) IT-02-54-T (12 December 2002a)

Prosecutor v. Milošević (Prosecution Motion for Reconsideration of the Trial Chamber's Refusal to Admit Certain Prosecution Exhibits During the Defence Case) (15 March 2005)

Prosecutor v. Milošević (Prosecution Notification of the Completion of its Case and Motion for the Admission of Evidence in Written Form) IT-02-54-T (25 February 2004a)

Prosecutor v. Milošević (Prosecution Reply to "Amici Curiae Submissions in Response to the Trial Chamber's Further Order on Future Conduct of the Trial Concerning Assignment of Defence Counsel' dated 6 August 2004") (19 August 2004)

Prosecutor v. Milošević (Prosecution Response to Amici Curiae Motion for Judgement of Acquittal Pursuant to Rule 98 bis (Public Version)) (3 May 2004)

Prosecutor v. Milošević (Prosecution Response to the 6 May 2003 Submission by Serbia and Montenegro Regarding Outstanding Requests for Assistance) IT-02-54-T (20 May 2003)

Prosecutor v. Milošević (Prosecution Submission in Response to the Trial Chamber's 21 July 2004 "Further Order on Future Conduct of the Trial Relating to Severance of One or More Indictments") IT-02-54-T (27 July 2004a)

Prosecutor v. Milošević (Prosecution Submissions in Response to the Trial Chamber's 19 July 2004 "Further Order on Future Conduct of the Trial") IT-02-54-T (26 July 2004b)

Prosecutor v. Milošević (Prosecution's Application for an Order Pursuant to Rule 54bis Directing the Federal Republic of Yugoslavia to Comply With Outstanding Requests for Assistance) IT-02-54-T (13 December 2002)

Prosecutor v. Milošević (Prosecution's Application for Leave to File an Interlocutory Appeal) IT-02-54-T (16 April 2002a)

Prosecutor v. Milošević (Prosecution's Interim Response to Assigned Counsel Request for Provisional Release) IT-02-54-T (22 December 2005a)

Prosecutor v. Milošević (Prosecution's Motion for Joinder) IT-99-37-PT, IT-01-50-PT, and IT-01-51-I (27 November 2001)

Prosecutor v. Milošević (Prosecution's Reply to the Serbia and Montenegro Response to the Prosecution's Application for an Order Pursuant to Rule 54 bis Directing the Federal Republic of Yugoslavia to Comply with Outstanding Requests for Assistance) IT-02-54-T (27 February 2003)

Prosecutor v. Milošević (Prosecution's Request for Leave to File a Reply Regarding Outstanding Requests for Assistance) IT-02-54-T (14 February 2003)

Prosecutor v. Milošević (Prosecution's Response to Accused's Objection to Admission of Intercepted Communications) IT-02-54-T (31 October 2002)

Prosecutor v. Milošević (Prosecution's Response to the "Preliminary Protective Motion" filed 9 August 2001) IT-99-37-PT (16 August 2001)
Prosecutor v. Milošević (Prosecution's Response to the "Presentation On The Illegality of ICTY" filed by the Accused Slobodan Milošević on 30 August 2001) IT-99-37-PT (13 September 2001)

Prosecutor v. Milošević (Prosecution's Submission of the Effect of the Appeals Chamber's Decision of 23 October 2003 Concerning Judicial Notice of Administrative Facts) IT-02-54-T (26 November 2003)

Prosecutor v. Milošević (Public Version Fifth Decision on Applications Pursuant to Rule 54bis of Prosecution and Serbia and Montenegro) IT-02-54-T (15 September 2003)

Prosecutor v. Milošević (Public version of First Decision on Admissibility of Supreme Defence Council Materials) IT-02-54-T (23 September 2004a)

Prosecutor v. Milošević (Public Version of the Confidential Decision on the Interpretation and Application of Rule 70) IT-02-54-108bis \& AR73.3 (23 October 2002)

Prosecutor v. Milošević (Public Version of the Confidential Decision on the Interpretation and Application of Rule 70) IT-02-54-AR108bis \& AR 73.3 (23 October 2003a)

Prosecutor v. Milošević (Public Version of the Confidential Decision on the Prosecution's Motion to Grant Specific Protection Pursuant to Rule 70) IT-02-54-T (25 July 2002)

Prosecutor v. Milošević (Reasons for Decision on Assignment of Defence Counsel) IT-02-54-T (22 September 2004)

Prosecutor v. Milošević (Reasons for Decision on Prosecution Interlocutory Appeal from Refusal to Order Joinder) IT-99-37-AR73, IT-01-50-AR73, IT-01-51-AR73 (18 April 2002)

Prosecutor v. Milošević (Reasons for Decision on the Prosecution Motion Concerning Assignment of Counsel) IT-02-54-T (4 April 2003)

Prosecutor v. Milošević (Reasons for Refusal of Leave to Appeal from Decision to Impose Time Limit) IT-02-54-AR73 (16 May 2002)

Prosecutor v. Milošević (Registry Report on Practical Facilities Available to the Accused) IT-02-54-T (18 March 2002)

Prosecutor v. Milošević (Report of Serbia and Montenegro Pursuant to Rulings Nos. 11 and 12 of the "Thirteenth Decision on Applications Pursuant to Rule 54 bis of Prosecution and Serbia and Montenegro" dated 17 December 2003) IT-02-54-T (17 February 2004)

Prosecutor v. Milošević (Request for Provisional Release pursuant to Rule 65) IT-02-54-T (20 December 2005)

Prosecutor v. Milošević (Request to the Registry Regarding Prosecution Report Pursuant to Ruling 9(a) of the Trial Chamber's Thirteenth Decision on Applications Pursuant to Rule 54bis of Prosecution and Serbia and Montenegro, Dated 17 December 2003) IT-02-54-T (16 January 2004)

Prosecutor v. Milošević (Response by the Amici Curiae to Prosecution's Motion for Judicial Notice of Adjudicated Facts Relevant to the Municipality of Brčko) IT-02-54-T (9 May 2002)

Prosecutor v. Milošević (Scheduling Order Concerning Recommencement of the Trial) IT-02-54-T (25 August 2004)

Prosecutor v. Milošević (Second Decision on Admissibility of Supreme Defence Council) IT-02-54-T (23 September 2004b)

Prosecutor v. Milošević (Second Decision on Prosecution Motion for Orders Pursuant to Rule 54bis against Serbia and Montenegro) IT-02-54-T (12 June 2003)

Prosecutor v. Milošević (Second Order Granting Leave to Amend the Croatia Indictment) IT-02-54-T (20 July 2004)

Prosecutor v. Milošević (Status Conference) IT-99-37-AR73, IT-01-50-AR73, IT-0151-AR73 (30 October 2001)

Prosecutor v. Milošević (Status Conference) IT-99-37-PT (30 August 2001a)

Prosecutor v. Milošević (Submission of Serbia and Montenegro Pursuant to the Chamber Order Issued at the Oral Hearing of 10 March 2003 Concerning the "Prosecution's Application for an Order Pursuant to Rule 54bis Directing the Federal Republic of Yugoslavia to Comply with Outstanding Requests for Assistance") IT-02-54-T (6 May 2003b)

Prosecutor v. Milošević (Submission of the Office of the Prosecutor on the Future Conduct of the Case in the Light of the State of the Accused's Health and Complexity of the Case) IT-02-54-T (8 November 2002)

Prosecutor v. Milošević (Supplement to Report of Serbia and Montenegro Pursuant to Rulings Nos. 11 and 12 of the "Thirteenth Decision on Applications Pursuant to Rule 54bis of Prosecution and Serbia and Montenegro" dated 17 December 2003) IT-02-54-T (23 February 2004)

Prosecutor v. Milošević (Third Decision on Prosecution Motion for Orders Pursuant to Rule 54bis against Serbia and Montenegro) IT-02-54-T (18 June 2003) 
Prosecutor v. Milošević (Third Order on the Use of Time in the Defence Case and Decision on Prosecution's Further Submissions on the Recording and Use of Time during the Defence Case) IT-02-54-T (19 May 2005)

Prosecutor v. Milošević (Thirteenth Decision on Applications Pursuant to Rule 54bis of Prosecution and Serbia and Montenegro) IT-02-54-T (17 December 2003)

Prosecutor v. Milošević (Warrant of Arrest Order of Surrender) IT-99-37-I (24 May 1999)

Prosecutor v. Milošević (Written Note by the Accused) IT-99-37-I Registry pages (3 July 2001c)

Prosecutor v. Milošević (Written Response of Serbia and Montenegro to "Prosecution's Application for an Order Pursuant to Rule 54bis Directing the Federal Republic of Yugoslavia to Comply with Outstanding Requests for Assistance") IT-02-54-T (7 February 2003)

Prosecutor v. Milošević, Case No. IT-02-54-T, Further Order on Future Conduct of the Trial, 19 July 2004; Further Order on Future Conduct of the Trial Concerning Assignment of Defence Counsel, 6 August 2004

Prosecutor v. Milošević, Case No. IT-02-54-T, Order Re-Scheduling and Setting the Time Available to Present the Defence Case, 25 February 2004, para 1.

Prosecutor v. Milošević, Case No. IT-02-54-T, Second Addendum to Assigned Counsel Request for Provisional Release pursuant to Rule 65 with Confidential Attachments E and F and Reply to Prosecution's Interim Response to Assigned Counsel Request for Provisional Release pursuant to Rule 65 with Confidential Attachments E and F, 22 December 2005. Although the attachments themselves are confidential, they are described in the Second Addendum, which was filed publicly. See Second Addendum, para. 5.

Prosecutor v. Milošević, Milutinović, Šainović, Ojdanić, and Stojiljković (Decision on Application to Amend Indictment and on Confirmation of Amended Indictment) IT-99-37-I (29 June 2001 b)

Prosecutor v. Milošević, Milutinović, Šainović, Ojdanić, and Stojiljković (Decision on Review of Indictment and Application for Consequential Orders) IT-99-37I (24 May 1999)

Prosecutor v. Milošević, Milutinović, Šainović, Ojdanić, and Stojiljković (Motion for Leave to File a Second Amended Indictment) IT-99-37-PT (filed 16 October 2001)

Prosecutor v. Milošević, Milutinović, Šainović, Ojdanić, and Stojiljković (Order of the President Assigning a Case to a Trial Chamber) IT-99-37-I (29 June 2001a)

Prosecutor v. Milošević, Milutinović, Šainović, Ojdanić, and Stojiljković IT-99-37-I (29 October 2001)

Prosecutor v. Milošević, Milutinović, Šainović, Ojdanić, and Stojiljković (Prosecution's Motion for Joinder) IT-99-37-PT; IT-01-50-PT; and IT-01-51-PT (27 November 2001)

Prosecutor v. Milošević, Milutinović, Šainović, Ojdanić, and Stojiljković (Preliminary Protective Motion, 9 August 2001; Presentation on the Illegality of ICTY) IT99-37-PT (30 August 2001)

Prosecutor v. Milošević, Milutinović, Šainović, Ojdanić, and Stojiljković, (Indictment) IT-99-37-I (23 May 1999)

Prosecutor v. Milošević, Milutinović, Ojdanić, Šainović, and Stojiljković (Substituted Decision on Motion to Amend Indictment) IT-99-37-PT (5 September 2002)

Prosecutor v. Milošević et al. (Prosecution's Corrigendum to Motion for Joinder Filed 27 November 2001 ("Motion for Joinder")) (10 December 2001)

Prosecutor v. Milutinović et al. (Judgement) IT-05-87-T (26 February 2009)

Prosecutor v. Milutinović et al. (Scheduling Order for Commencement of Trial) IT-05-87-T (28 June 2006)

Prosecutor v. Milutinović et al. IT-05-87-T (10 July 2006)

Prosecutor $v$. Tadić (Decision on the Defence Motion for Interlocutory Appeal on Jurisdiction) IT-94-1-AR72 (2 October 1995)

UNSC Res 1160 (31 March 1998) UN Doc S/RES/1160

UNSC Res 1244 (10 June 1999) UN Doc S/RES/1244

Rule 49 of the Rules, IT/32/Rev. 21 and not IT/32/Rev.44

Silber L, Little A (1996) The death of Yugoslavia. Penguin, London

Simons M (2004) Richard may, Milosevic judge, dies at 65., The New York Times, http://www.nytimes.com/2004/07/02/world/richard-may-milosevic-judgedies-at-65.html?_r=0. Accessed 30 Sept 2007

Statute of the International Criminal Tribunal for the former Yugoslavia (adopted 25 May 1993 UNSC Res 827)

Steinitz M (2005) The Milošević trial—live! An iconical analysis of international law's claim of legitimate authority. Journal of International Criminal Justice 3: $103-123$
Stephen C (2004) Judgement day, the trial of Slobodan Milošević. Atlantic Monthly, New York

Taylor T (1992) The anatomy of the Nuremberg trials: A personal memoir. Knopf, New York

The Prosecutor v. Milošević (Referral of Request to Withdraw, Deputy Registrar) IT-02-54 (27 October 2004b)

The Prosecutor v. Milošević (Withdrawal of Assigned Counsel) IT-02-54-T (27 October 2004a)

UNSC 'Report of the Secretary-General Pursuant to Paragraph 2 of Security Council Resolution 808' (3 May 1993) S/25704

UNSC Mechanism for International Criminal Tribunals (8 June 2012) MICT/1

UNSC Res 827 (25 May 1993) UN Doc S/RES/827

UNSC Res 955 (8 November 1994) UN Doc S/RES/955

\section{Submit your manuscript to a SpringerOpen ${ }^{\circ}$ journal and benefit from:}

- Convenient online submission

- Rigorous peer review

- Immediate publication on acceptance

- Open access: articles freely available online

- High visibility within the field

- Retaining the copyright to your article

Submit your next manuscript at $>$ springeropen.com 